Piotr Chomczyński

\title{
„Wielka wojna ojczyźniana" na plakatach sowieckich
}

\author{
Musimy pamiętać, że w czasie wojny mówi się, \\ $i \dot{z}$ po stronie wroga zawsze jest propaganda, \\ natomiast to co się mówi po naszej stronie jest prawda, \\ tym co wtaściwe, przykładem humanitaryzmu i walka o pokój ${ }^{1}$. \\ Walter Lippman
}

\section{Wstęp}

Celem niniejszego tekstu jest dokonanie historyczno-socjologicznej analizy plakatu sowieckiego z lat 1941-1945. Jest to czas, w którym Związek Radziecki przystąpił do wojny po stronie aliantów przeciwko państwom osi (III Rzesza, Włochy, Japonia). Okres ten jest bogaty w różne wydarzenia polityczne, militarne, gospodarcze i społeczne, $z$ drugiej natomiast strony pozwala badaczowi wyznaczyć klarowne ramy czasowo-przestrzenne, które stanowią "demarkację" obszaru badań. W tym przypadku analiza plakatów obejmuje jedynie plakaty powstałe w ZSRR w okresie 1941-1945.

Jednym z aspektów prowadzenia współczesnych działań zbrojnych jest wojna psychologiczna. Jej ważnym elementem jest propaganda wojenna, której istotnym narzędziem pozostają środki masowego przekazu

${ }^{1}$ Tłumaczenie własne. Walter Lippman, amerykański intelektualista, pisarz, polityk, autor publikacji z zakresu propagandy, stereotypów i zimnej wojny, autor m. in. książki Public opinion. 
(Tesar, Doppen 2007). Celem propagandy wojennej, podobnie jak szeroko rozumianych narzędzi wpływu, wykorzystywanych nie tylko w okresie prowadzenia działań zbrojnych, jest zazwyczaj propagowanie kolektywnych postaw, sposobów postrzegania rzeczywistości, lecz także wzbudzanie strachu, dumy, wstydu i innych emocji skłaniających do podejmowania pożądanych działań (Aronson, Wilson, Akert 1997: 317-337; Cialdini 2007: 248). Wpływ społeczny dokonuje się za sprawą stosowania wielu narzędzi masowego komunikowania, których skuteczność niejednokrotnie jest wysoko skorelowana z poziomem technologicznym kraju. O ile w bardziej rozwiniętych państwach (Europa Zachodnia, Stany Zjednoczone) istniał dość rozległy wachlarz możliwości uprawiania propagandy, o tyle Związek Radziecki, pomimo wyraźnie zauważalnych efektów implementowanej polityki uprzemysłowienia, nadal pozostawał krajem o relatywnie ograniczonych możliwościach komunikacyjnych. Oprócz szeroko wykorzystywanego radia i prasy, które docierały raczej do rejonów silnie zurbanizowanych, jedną z podstawowych ról propagandowych odgrywał plakat, eksponowany zarówno na otwartych przestrzeniach, jak i w miejscach użyteczności publicznej, urzędach, fabrykach itd. Narzędzie to zapewniało stały dostęp do przekazu osobom, które nie czytały prasy (wysoki wskaźnik analfabetyzmu), nie chodziły do kina, jak również nie posiadały, mało jeszcze popularnego w tych czasach, odbiornika radiowego. Przywódcy Związku Radzieckiego przywiązywali z tego powodu dużą wagę do plakatu jako narzędzia działań propagandowych², co sprawiło, że plakaciści radzieccy dysponowali dużym doświadczeniem konstruowaniu określonych przekazów. Z ich doświadczeń korzystał choćby obóz republikański w czasie wojny domowej w Hiszpanii w latach 1933-1936 (patrz tekst M. Melnyk Obraz hiszpańskiej wojny domowej na plakatach). W związku z niniejszymi okolicznościami można przyjąć, że plakat stanowił jedno $\mathrm{z}$ głównych narzędzi propagandowych używanych w Związku Radzieckim w czasie II wojny światowej, także propagandowo nazwanej wielką wojną ojczyźnianą (Bullock 1991).

Należy podkreślić, że naczelną zasadą oddziaływania społecznego, bez względu na to za pomocą jakich narzędzi się ono odbywa, jest jego skuteczność, która wynika ze spełnienia podstawowych założeń, na których opiera się proces komunikacyjny. Jak zauważa John Lyons, proces

2 Aleksander Sołżenicyn (1998) w dziele Archipelag Gułag poświęca dużo uwagi opisowi propagandy radzieckiej skierowanej zarówno "na zewnątrz”, jak i do obywateli radzieckich. 
komunikacji opiera się na umyślnym przekazywaniu informacji za pomocą ustalonego systemu sygnalizacyjnego, który musi być zakodowany w odpowiedni sposób przez nadawcę, by mógł zostać odkodowany przez odbiorcę (Lyons 1989: 35). Moim celem jest socjologiczna analiza znaczeń propagowanych $\mathrm{w}$ ramach plakatów wojennych. Na podstawie analizy treści plakatów, celów, którym służyły, jak również adresatów ich przekazów, wygenerowałem w sposób indukcyjny kategorie, na bazie przypisywanych wcześniej kodów. Więcej informacji na ten temat znajduje się w części metodologicznej tekstu.

\section{Koncepcja wielkiej wojny ojczyźnianej}

Pomimo że w niniejszej pracy pomijam analizę historyczną skupioną wokół zagadnień związanych $\mathrm{z}$ udziałem Związku Radzieckiego w II wojnie światowej, zdecydowałem się w kilku słowach przedstawić koncepcję wielkiej wojny ojczyźnianej, realizowanej także za pomocą plakatów wojennych.

Na skutek ataku III Rzeszy na Związek Radziecki i tym samym zerwania paktu o nieagresji pomiędzy ZSRR a III Rzeszą z 23 sierpnia 1939 r., zwanego paktem Ribbentrop-Mołotow, 22 czerwca 1941 r. ZSRR przystąpił do II wojny światowej po stronie aliantów. Alan Bullock podkreśla, że atak nastąpił $\mathrm{w}$ momencie, gdy kraj był do wojny nieprzygotowany zarówno $w$ aspekcie militarnym, jak i gospodarczym. Brak pełnej mobilizacji był $\mathrm{m}$. in. konsekwencją wcześniejszych "czystek” z lat trzydziestych, które objęły znaczną część doświadczonego korpusu oficerskiego. Ponadto w latach 1938-1940 przemysł stalowy i maszynowy, będący filarem industrializacji kraju, znacznie odbiegał od zakładanego poziomu przewidzianego planem pięcioletnim (Bullock 1991: 182).

Należy także wspomnieć, że wcześniejsze represje, jakich dopuściło się kierownictwo partii komunistycznej ZSRR, doprowadziły do znacznego spadku społecznego poparcia dla komunizmu utożsamianego ze Stalinem i jego poplecznikami. Bullock, lecz także Sołżenicyn opisują aktywne poparcie udzielane przez ludność krajów ZSRR (głównie krajów nadbałtyckich i Ukrainy) wojskom hitlerowskim wkraczającym na teren Związku Radzieckiego. Niektórzy historycy oceniają, że gdyby nie błędy Hitlera związane $\mathrm{z}$ okrutnym traktowaniem podbitych narodów oraz 
zmiana polityki wewnętrznej Stalina, ten pierwszy mógłby liczyć na wygraną. Nie zagłębiając się w szczegóły natury historycznej, chcę podkreślić, że Stalin i jego współpracownicy szybko zrozumieli konieczność podjęcia zdecydowanych działań propagandowych, mających na celu przywrócenie poparcia i wiary wśród obywateli ZSRR. Działania te znalazły silne odzwierciedlenie $\mathrm{w}$ tematyce plakatów wojennych. Jednym z pierwszych kroków na rzecz wzrostu poparcia dla działań Stalina było nazwanie $w$ jego radiowej przemowie z 3 lipca $1941 \mathrm{r}$. toczącej się wojny wielką wojną ojczyźnianą (Великая Отечественная война), со miało sugerować, że wojna rozgrywa się o najwyższą stawkę, jaką są losy ojczyzny, zagrożone przez hitlerowskiego najeźdźcę. Udział w wojnie został podniesiony do rangi bohaterstwa narodowego, które symbolizował przyznawany przez Prezydium Rady Najwyższej ZSRR Order Wojny Ojczyźnianej I i II stopnia.

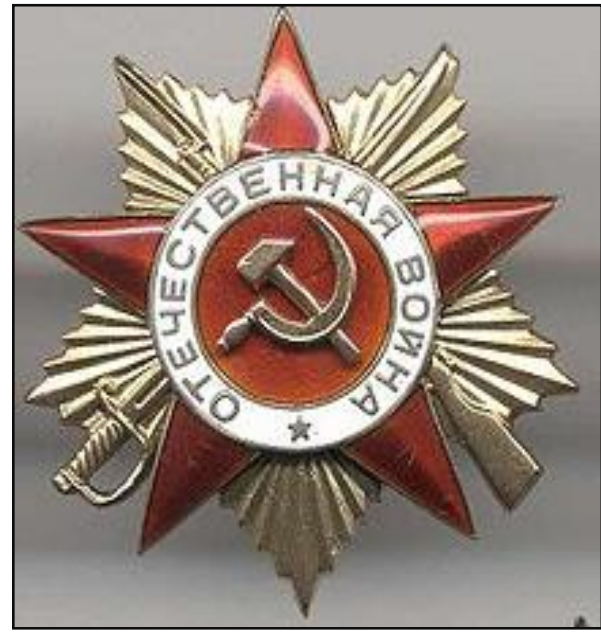

Rys. 1. Order Wojny Ojczyźnianej I stopnia

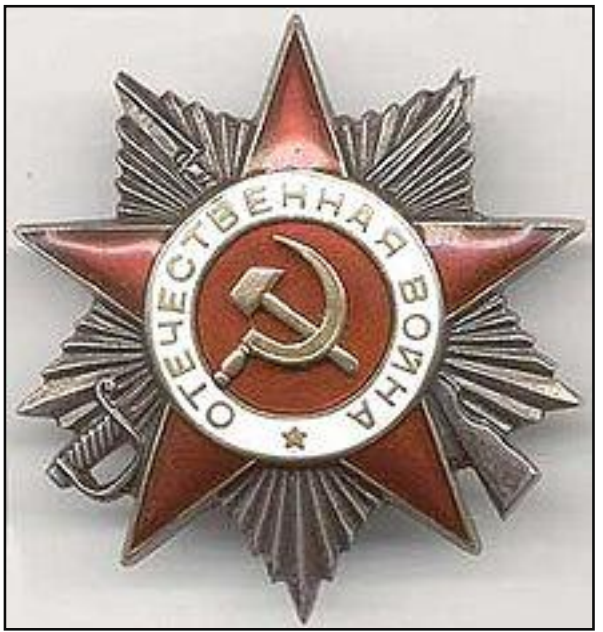

Rys. 2. Order Wojny Ojczyźnianej II stopnia

Powyższe działania miały na celu społeczną mobilizację ludności do stawienia czoła hitlerowskiej armii, która na początku działań bojowych odnosiła spektakularne sukcesy, zdobywając wiele miast Związku Radzieckiego. Wielkiego znaczenia propagandowego nabrała udana obrona Moskwy, która stanowiła zarazem pierwszą znaczną klęskę III Rzeszy, w ramach planu Tajfun, którego celem było zdobycie Moskwy. Niepowodzenia Hitlera związane były w głównej mierze z niesprzyjającymi 
warunkami pogodowymi, czyli surową zimą przypadającą na przełom 1941 i 1942 r. Fakt ten także został wykorzystany w działaniach propagandowych ZSRR poprzez sugestię, że również Matka Natura jest po stronie Rosjan. Ponadto, jak już wspomniałem, Niemcy, prześladując ludność podbitych terytoriów, nie byli w stanie zwerbować jej na swoją stronę, co w konsekwencji pomogło propagandzie sowieckiej stworzyć obraz III Rzeszy jako naturalnego wroga Związku Radzieckiego (por. Dominiak $^{3}$ 2003).

\section{Metodologia analizy plakatów wojennych}

Od czasu publikacji książki Ervinga Goffmana Gender Advertisements w roku 1979, powstało wiele prac w zakresie metodologii badań związanych z szeroko pojętym obrazem, ukazało się również dużo publikacji empirycznych, wspartych na bazie materiałów wizualnych. Różnorodność prowadzonych badań odzwierciedla w pewnym stopniu wielość stosowanych metodologii. Brak jednoznaczności w tym obszarze socjologii i relatywizacja tej kwestii wynika z samej natury obrazu, który ze względu na swą specyfikę stwarza znaczny margines interpretacyjny. Gregory C. Stańczak stwierdza, że „obrazy będą wywoływać odmienne skojarzenia zależnie od różnych pytań, jakie im zadajemy" (Stańczak 2007: 9), w zakresie stosowanych metod badawczych. Badacze, niejednokrotnie stojąc przed problemem interpretacji treści materiału wizualnego, $\mathrm{w}$ przypadku zdjęć, wspomagają się interpretacjami dokonywanymi przez samych autorów fotografii (patrz Konecki 2005) lub też zadają pytania rozmówcom, którzy nie są ich autorami, lecz artykułują własne sądy na temat obrazu (Frąckowiak 2008).

W niniejszej pracy podstawą analizy są materiały wizualne szczególnego charakteru, mianowicie plakaty. Wyznaczają one zakres możliwych metodologii, jak również technik, które mogą być wykorzystane. W tym przypadku zdecydowałem się na indukcyjny model budowania kategorii analitycznych, służących opisowi treści plakatów. Jest to nieco odmienny

${ }^{3}$ Autor w głównej mierze skupia się na kreowaniu w Związku Radzieckim „wroga ludu", jednakże część prezentowanego w artykule opisu znajduje zastosowanie w propagowanej koncepcji III Rzeszy jako „uniwersalnego” wroga Związku Radzieckiego. 
sposób niż na przykład ten zaproponowany przez Gillian Rose, a wykorzystany w niniejszej monografii przez Tomasza Ferenca $w$ analizie plakatów amerykańskich. Autorka proponuje wygenerowanie zbioru kategorii służących analizie materiału empirycznego. Kategorie te muszą służyć do opisu wszystkich elementów zbioru (plakatów), powinny być wyczerpujące, czyli uwzględniać wszystkie aspekty zgromadzonego materiału, powinny być też rozdzielne i pomocne w analizie wizualnej (Rose 2006: 56-60, także Ferenc 2007).

$\mathrm{W}$ podjętej przeze mnie analizie postanowiłem wybrać inną drogę, gdyż mój materiał badawczy stanowiła tylko jedna grupa plakatów (radzieckich), w związku z czym nie dokonywałem porównań na podstawie wcześniej wyodrębnionych kategorii. Podobną perspektywę analityczną wykorzystał w niniejszej książce Waldemar Dymarczyk w swoich rozważaniach na temat posterów okresu wojny polsko-bolszewickiej.

Wykonana przeze mnie analiza plakatów wojennych dzieliła się na kilka etapów. W procesie gromadzenia bazy ilustracji najbogatsze okazały się zbiory umieszczone w Internecie. Plakatów szukałem głównie na stronach poświęconych plakatom radzieckim okresu II wojny światowej. Szczególnie przydatna okazała się strona internetowa http://eng.plaka ty.ru/, na której umieszczone były pozycje skatalogowane według daty, podane były również nazwiska twórców plakatów. Pracy wymagały natomiast tłumaczenia haseł i sloganów umieszczone na stronie. W celu weryfikacji danych zawartych na niniejszej stronie, jak również poszerzenia bazy zgromadzonych przeze mnie zbiorów odwiedziłem także inne strony m. in. http://www.rosjapl.info/rosja/plakat_wojna.php. Kolejnym etapem było dokonanie kategoryzacji zgromadzonych obrazów. Postanowiłem tu wykorzystać indukcyjny schemat analizy, który polegał na zbadaniu wszystkich zgromadzonych przeze mnie plakatów (80 sztuk) i zastosowaniu kodowania otwartego (Strauss, Corbin 1990: 65), którym objąłem zarówno obraz, jak i jego opis (tytuł plakatu, zdania, sentencje, dialogi, cytaty itd., stanowiące integralną część plakatu). Dzięki temu zwiększyłem prawdopodobieństwo poprawnego odczytu warstwy znaczeniowej plakatu, która opierała się na nierozerwalnej relacji tekstu i obrazu. W rezultacie kodowania otwartego wyodrębniłem etykiety, które następnie pozwoliły mi utworzyć kategorie. W dalszej części pracy rozpocząłem proces kodowania selektywnego (Strauss, Corbin 1990: 116-142) kolejnych plakatów celem nasycenia wcześniej wyodrębnionych kategorii. Gdy kolejno analizowane plakaty nie wzbogacały już własności kategorii, uznałem, że uzyskałem zadowalający poziom ich 
nasycenia (nasycenie teoretyczne). Następnie ponownie przeanalizowałem wszystkie zgromadzone plakaty, dobierając do egzemplifikacji kategorii jedynie te, które w najbardziej wyraźny sposób je obrazowały.

Budując kategorie, jak już wspomniałem, oparłem się na warstwie semantycznej plakatu, lecz także wziąłem pod uwagę cel, jakiemu miał on służyć. Niektóre plakaty, ze względu na charakteryzujący je eklektyzm znaczeniowy, obrazowały więcej niż jedną kategorię. Mam ponadto świadomość, że wyodrębnione przeze mnie podziały, z racji ograniczonej liczby wyemitowanych plakatów, nie wyczerpują wszystkich możliwości, a sygnalizują jedynie główne wątki widoczne w plakacie radzieckim okresu wielkiej wojny ojczyźnianej.

W tym miejscu chciałbym przybliżyć wygenerowane przeze mnie kategorie analityczne i w paru słowach dokonać ich charakterystyki. Na podstawie analizy 80 plakatów udało mi się wyodrębnić następujące kategorie:

1) Hitler i jego otoczenie. Ta kategoria zawiera motyw sylwetki Adolfa Hitlera przedstawianego jako głównego bohatera plakatu lub jego najbliższego otoczenia.

2) Żołnierz niemiecki i armia niemiecka. $W$ ramach tej kategorii analizie poddane zostały te plakaty, w których główna rola przypadła żołnierzowi niemieckiemu, w przypadku zastosowania perspektywy indywidualistycznej lub armii, w razie spojrzenia kolektywistycznego.

3) Armia Czerwona. Działania propagandowe obejmowały także ukazywanie w pozytywnym świetle Armii Czerwonej i jej osiągnięć, co odzwierciedla ta kategoria.

4) Obrona ludu rosyjskiego. Niniejsza kategoria skupia plakaty, w których przeważa motyw działań podjętych w celu obrony ludności przed agresją wojsk niemieckich.

5) Ojczyzna (Matka Rosja). Kategoria ta odnosi się do często występującego wątku personalizacji ojczyzny przedstawianej pod postacią matki.

6) Militarne wsparcie cywili. W ramach tej kategorii analizie poddane zostały plakaty, w których władza państwowa adresatem przekazu czyniła cywilów, zachęcając ich do stawiania oporu w obliczu wroga.

7) Środki ostrożności. Kategoria „środki ostrożności” odnosi się do tych plakatów, które kształtowały postawy nieufności we wzajemnych kontaktach celem zapobieżenia ujawnienia wrogowi informacji tajnych.

8) Wsparcie cywili o charakterze niemilitarnym. Ważną kategorię plakatów stanowią te, które odnoszą się do propagowania postawy biernego oporu cywilów wobec najeźdźcy. 
9) Historia. Ta kategoria plakatów odnosi się do wykorzystania motywów historycznych w przekazach akcentujących przeszłe zwycięstwa i ich bohaterów.

\section{Wyniki analizy plakatów wojennych}

\section{1) Hitler i jego otoczenie}

Ta kategoria obejmuje plakaty, które w różnych kontekstach sytuacyjnych zawierały sylwetkę Adolfa Hitlera. Pomimo oczywistego faktu, że jest on przez radzieckich plakacistów zawsze przedstawiany w sposób pejoratywny, to zmienia się zarówno perspektywa, z jakiej twórca plakatu postrzega Hitlera i interpretuje jego działania, lecz także dobór atrybutów, które go charakteryzują w konkretnym plakacie. Twórca plakatu pragnie powiązać, $\mathrm{w}$ oczach jego adresatów, Hitlera $\mathrm{z}$ określonym „fragmentem zła" ${ }^{4}$ uosabianego z nim. Istotna jest tutaj też perspektywa czasowa emisji plakatów, która odzwierciedla kolejne, aktualne wydarzenia militarne i polityczne. $\mathrm{W}$ pierwszym okresie wojny, tj. od czerwca 1941 r., Hitler jest przede wszystkim przedstawiany jako zdrajca, który w sposób jednostronny złamał postanowienia wynikające $\mathrm{z}$ paktu Ribbentrop-Mołotow. Jest nielojalny, gdyż nie respektuje bilateralnych umów, kierując się doraźnymi korzyściami. Na plakacie 1 jest on ukazany jako chciwiec. Zamiast dłoni posiada kleszcze, które po podarciu paktu o nieagresji są pazernie zwrócone $\mathrm{w}$ kierunku wschodnim. Unieszkodliwiają je dopiero trzymane ludzką dłonią narzędzia, także przypominające kleszcze. Być może zamysłem autora plakatu było przekazanie informacji, że działania wymierzone przeciwko niemu będą miały identyczny charakter (wet za wet) jak te, które on sam zastosował wobec lojalnego sojusznika. Postać Hitlera jest wynaturzona, lecz mimika jego twarzy wskazuje na strach, rozczarowanie i daremny wysiłek symbolizowany przez widoczny pot kapiący z twarzy. Identyfikacji zmagających się stron dodatkowo służą symbole władzy III Rzeszy i Związku Radzieckiego. $\mathrm{W}$ podobnym tonie utrzymany jest plakat 2, na którym fizjo-

${ }^{4}$ Pomimo że Hitler jako postać był uosabiany ze złem, to jednak plakaciści starali się uwypuklić do rozmiarów karykaturalnych wybrane obszary osobowości, zachowania, preferencji Hitlera. 
nomia i mimika Hitlera została przedstawiona w sposób niemal identyczny, z tą różnica, że pozostawia on mniej swobody interpretacji. Z drugiego plakatu dokładnie wiemy, o jaką zdradę Hitlera chodzi, gdyż nazwa paktu znajduje się na plakacie. Wyjaśniona jest także kwestia tego, kto zahamuje działania zdrajcy. Żołnierz Armii Czerwonej ma na twarzy wypisany gniew, który kontrastuje $\mathrm{z}$ wyrazem zaskoczenia i niemocy widocznej na twarzy Hitlera. Na drugim plakacie także w większym stopniu widać zróżnicowanie barw. Kolor czarny zarezerwowany jest dla Hitlera, czerwony zaś dla czerwonoarmisty. Ta prawidłowość jest oddana też $\mathrm{w}$ napisach umieszczonych na plakacie a będzie powielana również na innych plakatach.

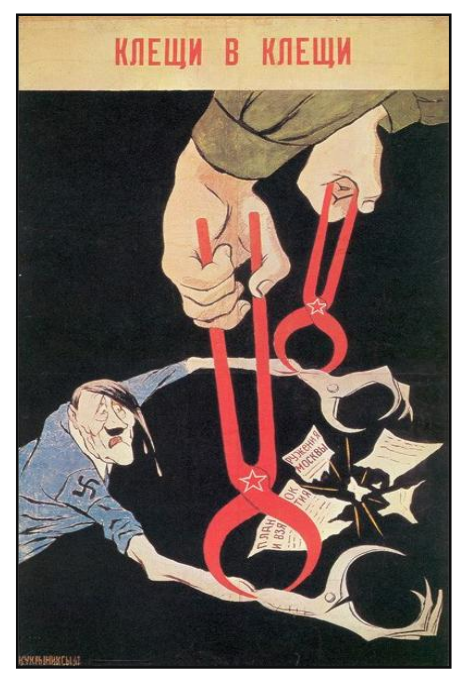

Plakat 1

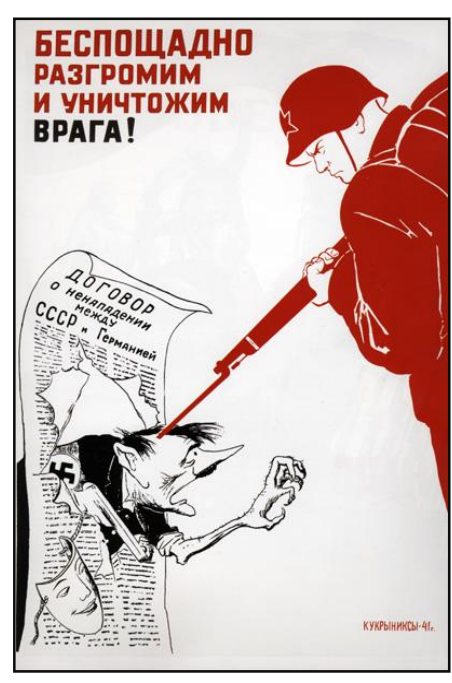

Plakat 2

Motyw dwulicowej natury Hitlera pojawił się także na kolejnym plakacie (plakat 3), który ukazuje jego naturę z nieco innej perspektywy. Tytuł plakatu Ludojad - wegetarianin. Dwie strony medalu sugeruje, że wódz III Rzeszy jest wilkiem w owczej skórze, który podając się za osobę łagodną jednocześnie jest katem. $Z$ jednej strony głaszcze małą owieczkę, kojarzącą się z łagodnością i niewinnościa, podczas gdy w drugiej odsłonie zabija strzałem $\mathrm{w}$ głowę spętaną kobietę, prawdopodobnie matkę (obok widać dziecko). Plakat sugeruje lustrzane odbicie z wyraźnie zaznaczoną linią symetrii, co ma dodatkowo sugerować janusowe oblicze Hitlera. 


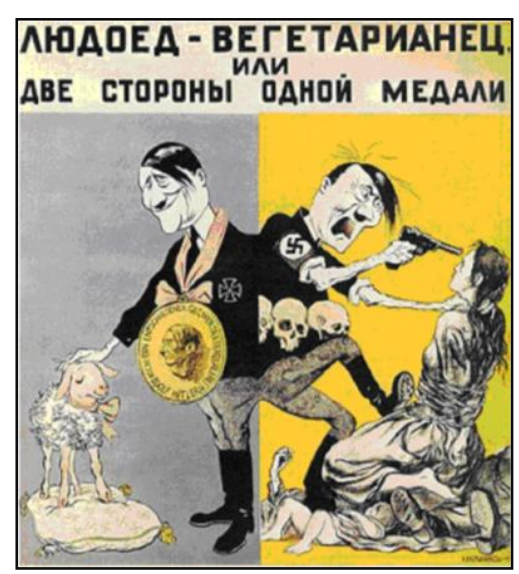

Plakat 3

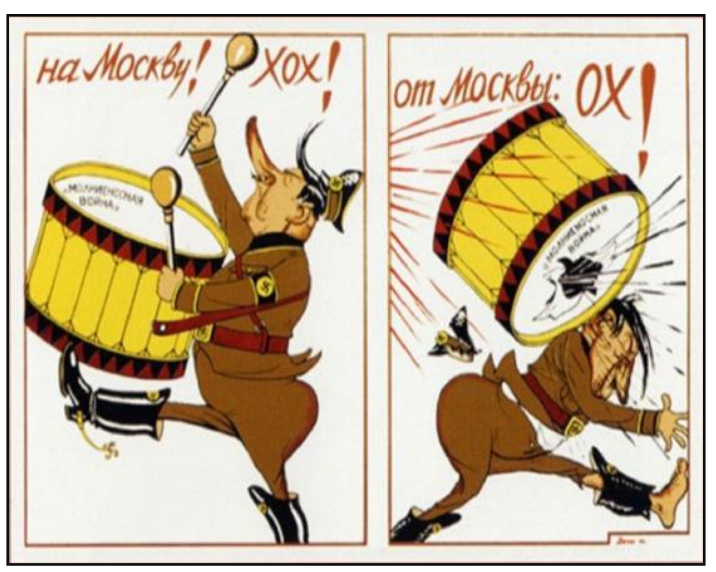

Plakat 4

Kolejny plakat (4) utrzymany jest w konwencji radzieckiej propagandy sukcesu, która wykorzystywała, wspomnianą już przeze mnie, nieudaną próbę zdobycia Moskwy przez wojska niemieckie. Hitler jest tutaj przedstawiony jako dobosz ${ }^{5}$, który paradnym krokiem wiedzie wojska na Moskwę. Wyprostowana postawa i głowa zadarta do góry wskazują na zadufanie $\mathrm{w}$ sobie, zdecydowanie kontrastuje to $\mathrm{z}$ sytuacją przedstawioną po prawej stronie, gdzie w zniszczonym ubraniu salwuje się ucieczka, nieprzy pominającą zorganizowanego odwrotu. Hitler oczywiście uosabia tutaj niemiecką armię, która doznała pierwszej klęski, przede wszystkim o znaczeniu symbolicznym. Klęska ta pozwala obalić mit niezwyciężonej niemieckiej armii i podnieść wiarę w zwycięstwo.

Część plakatów przedstawiała Hitlera oraz osoby z grona jego najbliższych współpracowników, zazwyczaj ministrów i wyższych oficerów. Na jednym z plakatów, którego celem było obnażenie działania machiny propagandowej wroga, uwidoczniony jest Adolf Hitler "obsługujący" Josepha Goebbelsa przedstawionego pod postacią karabinu maszynowego, którego amunicję stanowią zapisane kartki papieru. Przekaz uwidacznia kilka elementów, m. in. taki, że minister propagandy jest całkowicie uzależniony od woli Führera, którego główną bronią jest propaganda. Można domniemywać, że twórca plakatu chciał zasugerować, że innej broni Hitler nie posiada, a jego sukcesy są w dużej mierze zmyślone.

${ }^{5}$ W latach dwudziestych i trzydziestych Hitler był nazywany „doboszem” ruchu narodowo-socjalistycznego planującym przewrót i objęcie władzy (Kershaw 2001). 


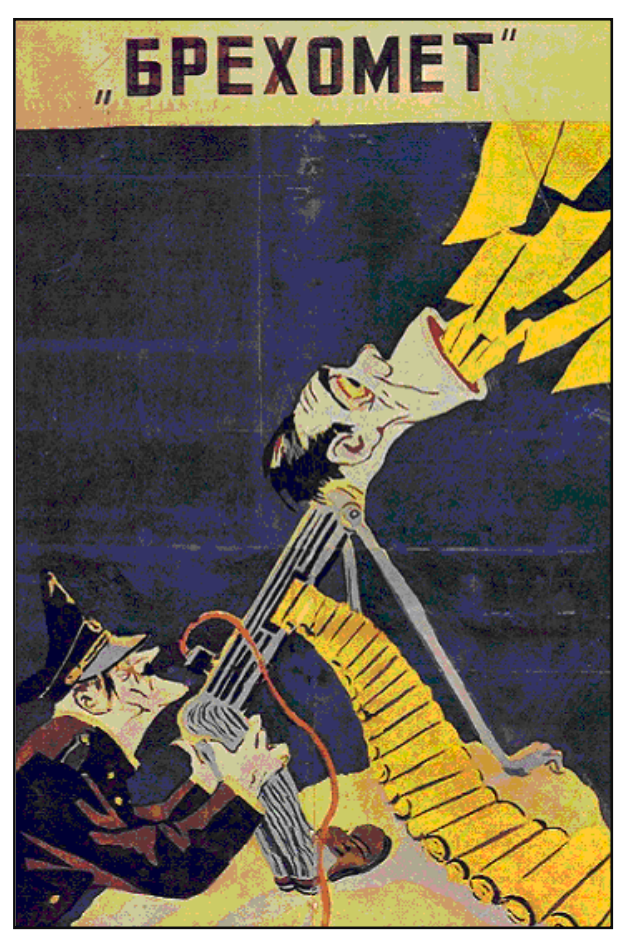

Plakat 5

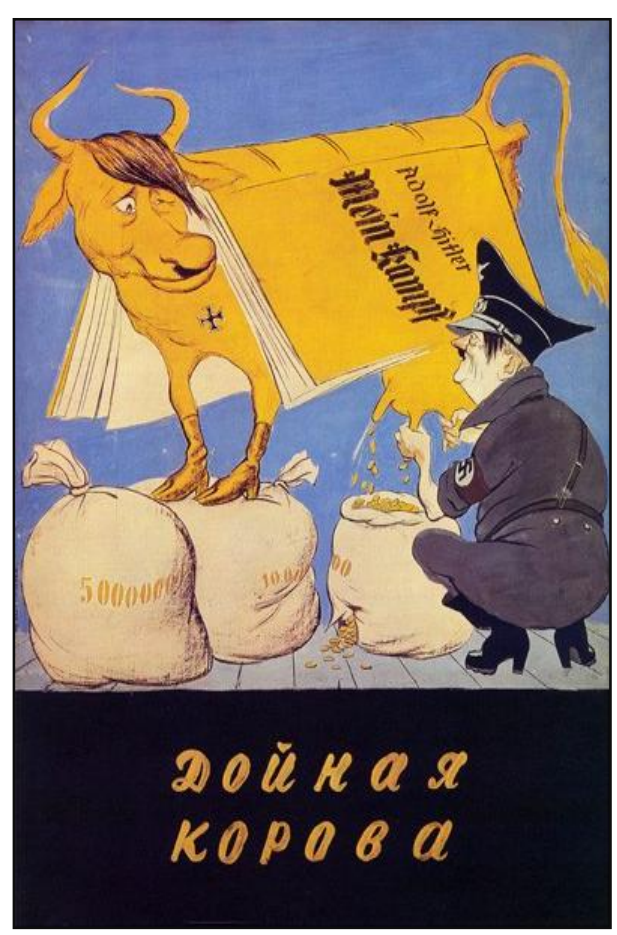

Plakat 6

Wśród plakatów, na których widniał wizerunek Hitlera, można wyodrębnić także te, które przedstawiają go jako wroga własnego narodu, wbrew pokładanym w nim nadziejom, niewalczącego o jego dobro, lecz przyczyniającego się do klęski. Plakat 6 z roku 1942 propaguje obraz Hitlera jako przywódcy, który wyzyskuje własny naród. Można się domyślać, że twórca plakatu nie bierze $\mathrm{w}$ obronę narodu niemieckiego, mającego na plakacie postać krowy o wizerunku Hitlera. Zwierzę przykryte jest książką jego autorstwa Mein Kampf, co może sugerować, że naród uwierzył $\mathrm{w}$ zawarte $\mathrm{w}$ niej tezy. $\mathrm{W}$ miarę rozwoju sytuacji na froncie wschodnim, gdy scenariusz przegranej III Rzeszy stawał się coraz bardziej realny, wyraźnie zaznaczyła się tendencja do ukazywania wodza Niemiec jako osoby niezrównoważonej psychicznie, niezdolnej do oceny ryzyka i podejmowania logicznych decyzji. Na plakacie 7 Hitler jest przedstawiony jako strateg, który jedynie planuje, podczas gdy rzeczywiste działania stają się udziałem Armii Czerwonej. Plakat sugeruje, że przywódca Niemiec jest teoretykiem, który bez powodzenia próbuje 
zmierzyć się ze skuteczniejszym wrogiem. Na kolejnym plakacie (8) autor odwołuje się $\mathrm{w}$ wyraźny sposób do kompetencji intelektualnych Hitlera i jego zdrowia mentalnego. Jest on tu przedstawiony w komicznej sytuacji udzielania audiencji jednemu ze swoich generałów. Przedstawiony kontekst nie pozostawia złudzeń interpretacyjnych - wódz III Rzeszy jest niepoczytalny i nie jest w stanie dłużej dowodzić.

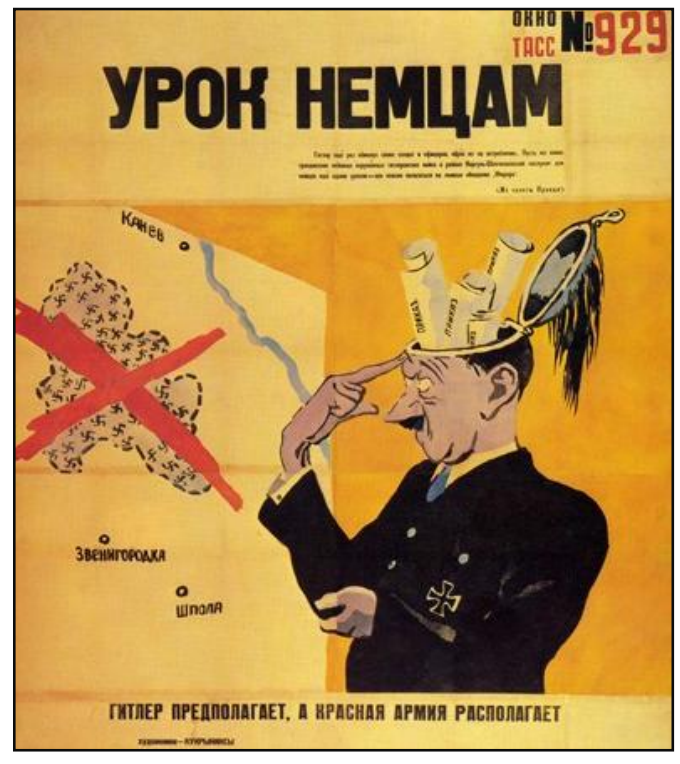

Plakat 7

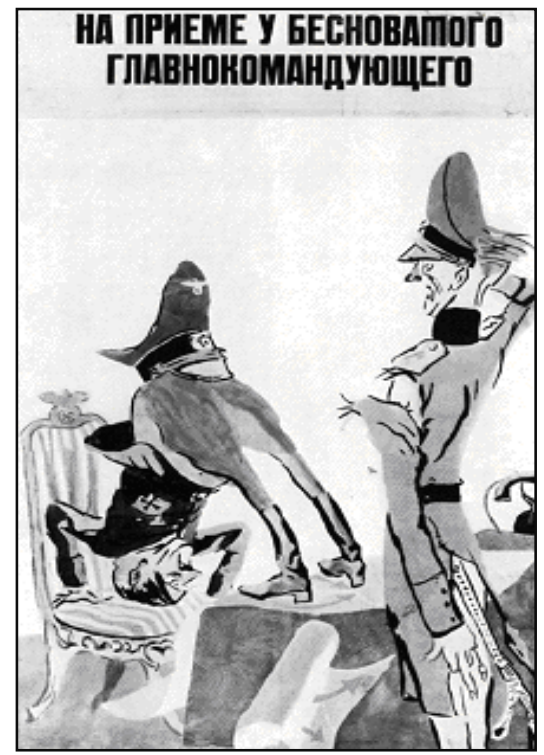

Plakat 8

Ostatnia grupa plakatów (9 i 10) przepowiada osobistą klęskę Hitlera, która jest nieuchronna. Obraz 9 nawiązuje do omówionego przeze mnie na początku plakatu, w którym także zamieszczono artefakt symboliczny w postaci szczypiec lub obcęgów. W zestawieniu z nim plakat 9 wydaje się kontynuacją i spełnieniem przyrzeczenia danego narodowi w chwili ataku z 22 czerwca 1941 r. Plakat jasno wskazuje, że klęska Hitlera nastąiła po trzech latach zmagań wojennych. W nieco innym klimacie utrzymany jest plakat 10 zatytułowany Ostatni numer programu. $\mathrm{Na}$ plakacie Hitler jest ukazany jako kataryniarz, którego towarzyszami są jedynie papuga, nawiązująca do cyrkowego charakteru sytuacji, oraz Joseph Goebbels przedstawiony w postaci małpy. Także i w tym przypadku przywódca III Rzeszy jest ubezwłasnowolniony w swoich działaniach. Koniec Hitlera zwiastuje podobizna śmierci widniejąca z tyłu za plecami głównych aktorów dramatu. 


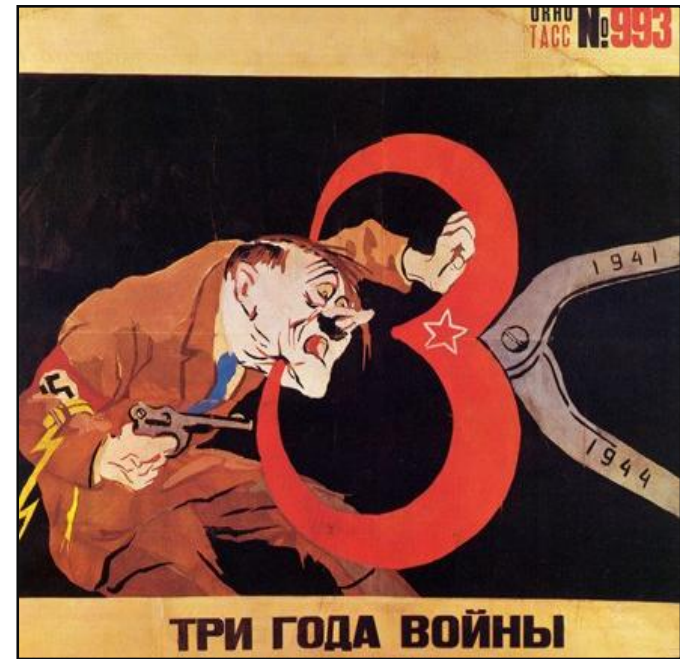

Plakat 9

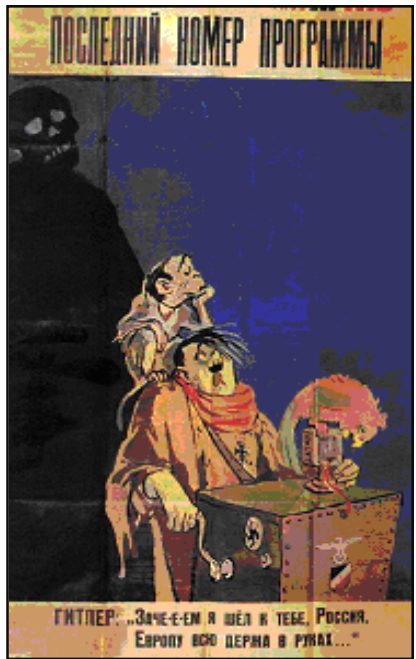

Plakat 10

\section{2) Żołnierz niemiecki i armia niemiecka}

Kolejną kategorię plakatów stanowią te, które przedstawiają niemieckiego żołnierza oraz niemiecką armię. Wizerunek niemieckiego żołnierza stanowi personalizację armii, która zyskuje tym samym rys ludzki. Podobna prawidłowość znalazła zastosowanie w przypadku plakatów z przedstawieniem Hitlera, będącego symboliczną twarzą III Rzeszy. Plakat 11 ukazuje zestrzelony samolot. Charakter propagandowy tego przekazu, oprócz nagłaśniania skuteczności podejmowanych przez stronę radziecką działań, polega także na podkreśleniu faktu, że technologiczna dominacja III Rzeszy, widoczna zwłaszcza na początku agresji niemieckiej, nie ma dużego znaczenia wobec zaciekłej obrony. Plakat 12 przekonuje, że ciosy radzieckie padają jak gromy. Na plakacie jest umieszczony niemiecki dowódca, który spoczywając na ludzkich czaszkach, otrzymuje śmiertelny cios. Wyciągnięta przed siebie ręka, jak również sama pozycja leżąca, może świadczyć o nieskutecznej obronie. Ważna propagandowo pozostaje także symbolika miasta - Stalingradu, która nawiązuje do skutecznej obrony, podobnie jak było to w przypadku Moskwy. Motyw konkretnego miejsca, które udało się obronić, pojawia się często w plakatach, gdyż symbolizuje rzeczywistą skuteczność działań obronnych wspieraną nazwami miast głęboko osadzonych w zbiorowej świadomości adresatów przekazu. 


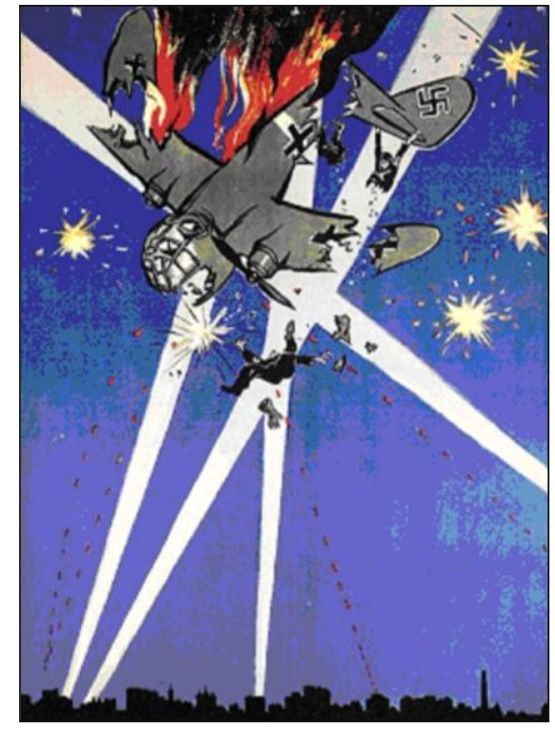

Plakat 11

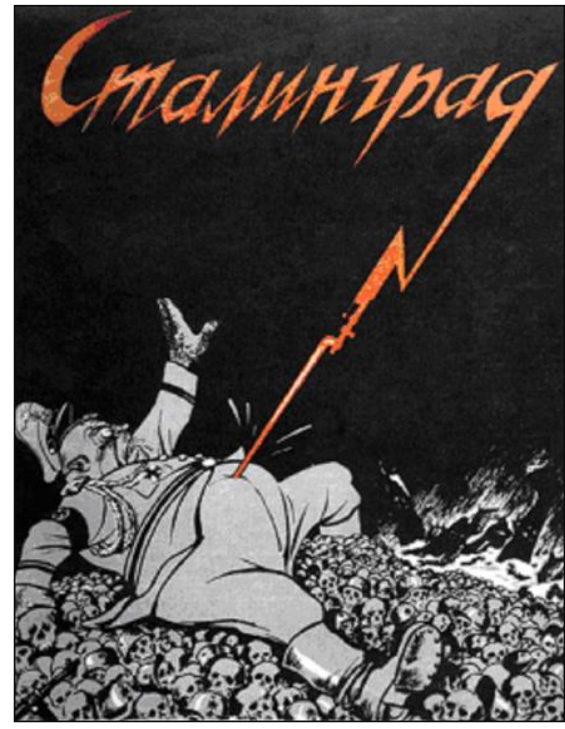

Plakat 12

Kolejną grupę plakatów stanowią te, które przedstawiają „typowego" młodego żołnierza niemieckiego jako człowieka sadystycznego, kierującego się najniższymi pobudkami, w sposób mechaniczny i bezwolny zmienianego przez tryby machiny wojennej w profesjonalnego mordercę. Na plakacie 13 ukazana jest perspektywa czasowa odsłaniająca elementy kariery młodego Niemca, umownie zwanego Fritzem.

Niniejszy plakat przekonuje, że młodzi ludzie rekrutowani do niemieckiej armii mają „,z gruntu” złą naturę, w związku z tym potrafią się w niej odnaleźć. Niemiecka armia jest formacją zdemoralizowana, w której realizować się mogą tylko jednostki zdeprawowane, które angażowały się w hańbiące zajęcia od najmłodszych lat. Następny plakat, choć także odnosi się do umownego „Fritza”, ukazuje los, jaki czeka jego i jemu podobnych. Tytułowa Transformacja odnosi się do nieuniknionej zagłady pod przywództwem Hitlera przedstawionego po lewej stronie w geście powitalnym, wskazującego jednocześnie kierunek zmian. Na nieuchronny los armii hitlerowskiej wskazują także krążące ptaki, kojarzone z miejscem pochówku lub tragicznej śmierci. W kilku innych plakatach związanych z motywem „Fritza” jest on przedstawiany jako osoba niezdarna, o niskich kompetencjach intelektualnych itd. Celem tych obrazów jest przekazanie informacji, że armia niemiecka składa się właśnie z takich żołnierzy, dlatego nie należy się jej obawiać. Ów zabieg miał 


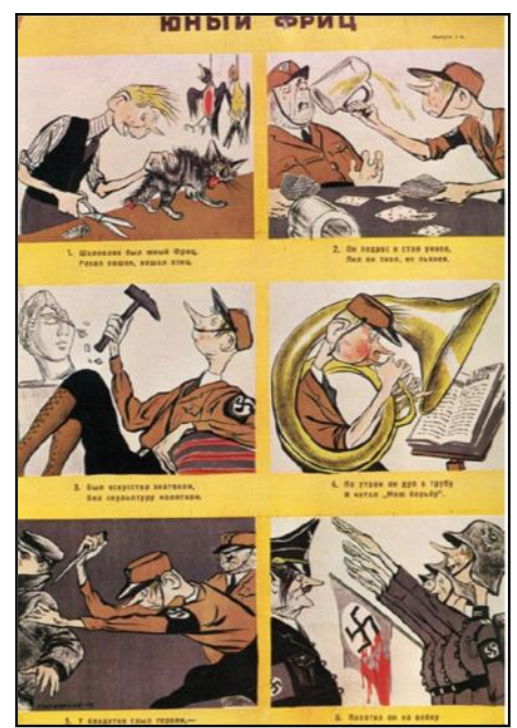

Plakat 13

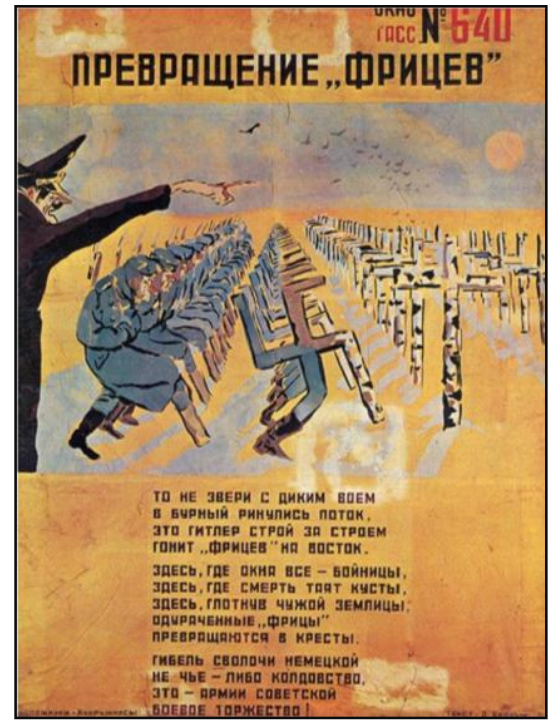

Plakat 14

na celu z jednej strony deprecjonowanie żołnierzy niemieckich, a z drugiej zaś podwyższenie morale żołnierzy Armii Czerwonej, którzy niejednokrotnie demonizowali siłę i wyposażenie militarne wroga. $W$ zupełnie innym klimacie semantycznym utrzymany jest plakat 15 . Żołnierz niemiecki przedstawiony jest jako okrutny morderca, który nie posiada najbardziej podstawowych zasad moralnych, mianowicie zabija matkę na oczach dziecka. Po lewej stronie plakatu, w tle widoczne są szubienice z wisielcami. Intencją plakacisty jest wzbudzenie odrazy i strachu przed działaniami wroga, które mają wyzwolić działania obronne, niezwykle potrzebne $\mathrm{w}$ roku 1942. W razie niepowodzenia tak będzie wyglądała klęska. Fragment podpisu pod plakatem brzmiał Za honor żony, za życie dzieci, za szczęście Ojczyzny... i kanalizował wzbudzane obrazem emocje, łącząc je z określonym celem.

Plakat 16 pochodzący z roku 1944 pokazuje odwrót pokonanej armii wroga, także i w tym przypadku silnie związanej z podobizną Hitlera. Wyraźnie zauważalna dysproporcja pomiędzy żołnierzem Armii Czerwonej ogromnie górującym nad pokonanym wrogiem, sugeruje także przewagę nad armią hitlerowską. Przewaga ta dodatkowo pogłębia się na skutek warunków pogodowych, które w propagandzie sowieckiej wykorzystywane były dość często z sugestia, że zazwyczaj bezstronna natura tym razem opowiada się po stronie obrońców. 


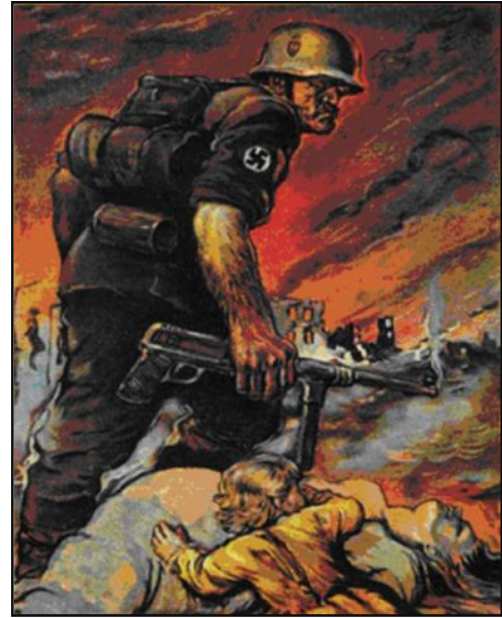

Plakat 15

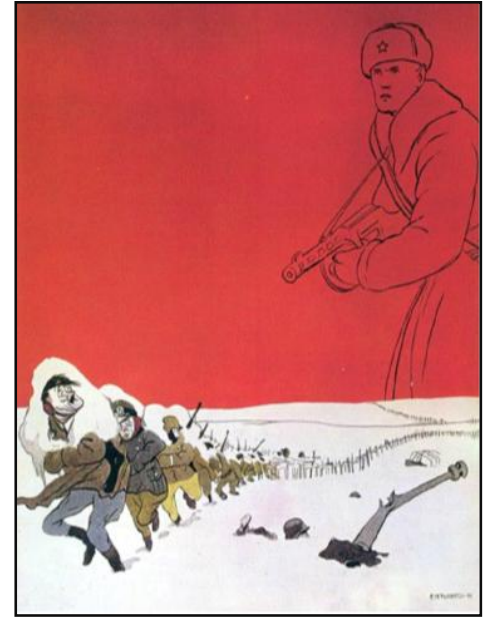

Plakat 16

\section{3) Armia Czerwona}

Kolejną grupę plakatów stanowią te, które przedstawiają Armię Czerwoną. Podobnie jak w przypadku plakatów obrazujących wroga, tak i tutaj zastosowana jest perspektywa mikro i makro. Pierwsza z nich najczęściej prezentuje jednego, wybranego żołnierza bądź niewielką ich grupę, podczas gdy na innych widnieje wielu żołnierzy, którzy uosabiają potęgę armii. Zdecydowanie najczęściej mamy do czynienia z pierwszą perspektywą lub połączeniem obu. Dzięki temu zabiegowi, armia traci charakter nieprzekonującej ludzkiej masy, natomiast zyskuje bardziej konkretny, personalny obraz, bogaty w szczegóły, takie jak: mimika twarzy, postura, wyposażenie bojowe oraz symbole zwycięstwa, odwagi, potęgi siły itd. Armia Czerwona często przedstawiana jest na tle rzeczywistych wydarzeń lub przekaz odnosi się do symboliki państwowej, która jest dobrze znana dla większości adresatów.

Na plakacie 17 widzimy żołnierza radzieckiego, który powala wroga. Obie postacie mają charakter rzeczywisty i są przedstawione w sytuacji walki wręcz na bagnety. Zamysłem autora plakatu było podniesienie realizmu przekazu, który ma odzwierciedlać typową sytuację frontową. Zwycięstwo dodatkowo wzmocnione jest wizerunkiem zniszczonego, niemieckiego czołgu (widoczna na pojeździe swastyka). Budynek w tle, z symboliką państwową przekonuje, że mamy do czynienia z obroną 
ojczyzny, że walka toczy się na terytorium Związku Radzieckiego i odpowiada aktualnej sytuacji militarnej. Podobne plakaty odnosiły się do kolejnych miast, które dzięki Armii Czerwonej nie wpadły w ręce wroga. Plakaty tego typu dotyczą wydarzeń, które rozgrywają się tu i teraz.

Na kolejnym plakacie zastosowane jest, wspomniane już wcześniej, połączenie perspektyw mikro i makro. Na obrazie dostrzegamy atakujących żołnierzy radzieckich wspomaganych lotnictwem i bronią pancerną. Plakat ma budować i umacniać poczucie potęgi Armii Czerwonej, która, wbrew sytuacji rzeczywistej, jest dobrze wyposażona i zaawansowana technologicznie.

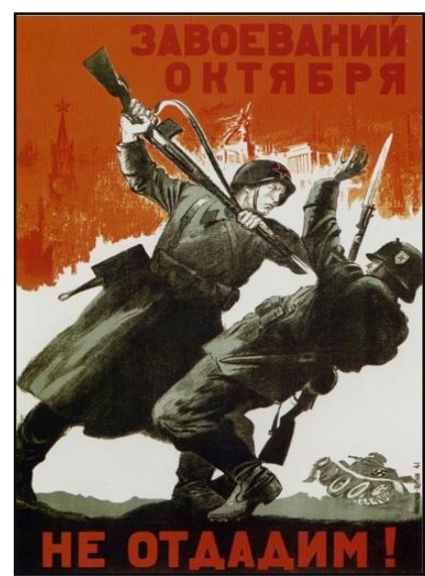

Plakat 17

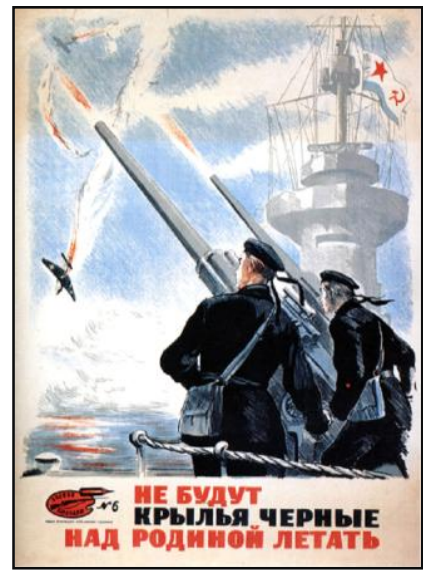

Plakat 19

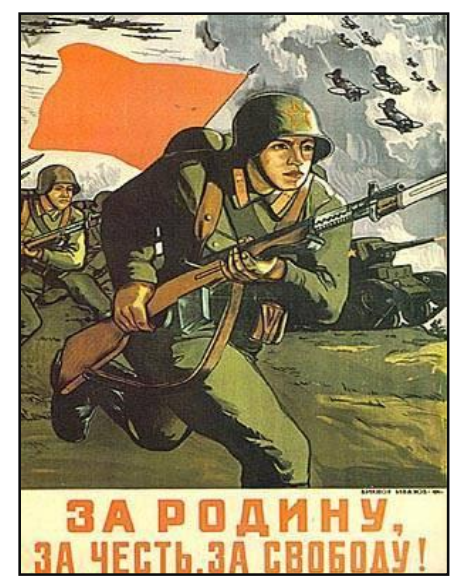

Plakat 18

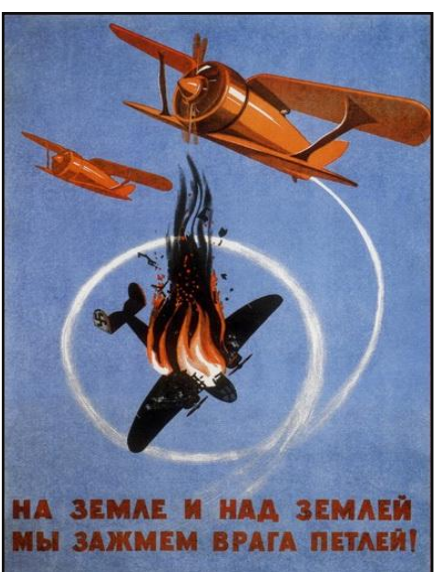

Plakat 20 
Wielkość Armii Czerwonej była dodatkowo podkreślana przez ukazywanie różnych rodzajów wojsk. Oprócz piechoty i wojsk pancernych przedstawiano także marynarkę wojenną (plakat 19) i lotnictwo (plakat 20).

Osobną grupę plakatów stanowiły te obrazujące heroizm i poświęcenie żołnierza radzieckiego. Plakat 21 ukazuje radzieckiego marynarza, który pomimo odniesionych ran czynnie uczestniczy w obronie. Warto zauważyć, że bohater plakatu nie jest przedstawiony $\mathrm{w}$ naturalnym dla siebie kontekście, tj. w pobliżu okrętu, lecz w okopie. Ociekający krwią marynarz, symbolizujący męczennika poświęcającego swoje życie w słusznej sprawie, walczy na lądzie, pośród ciał żołnierzy własnej armii. O zawziętej walce, w obliczu nadchodzącej śmierci, świadczy brak broni palnej, a jedynie dostępne granaty. Im przewaga wojsk radzieckich nad niemieckimi stawała się coraz bardziej wyraźna, tym częściej pojawiały się plakaty ukazujące zwycięstwo mające nadejść lub już osiągnięte. Plakat 22 z roku 1945 ukazuje żołnierza radzieckiego w blasku zasłużonej chwały. Symbolika państwowa ma postać promieniejącej gwiazdy z napisem wojna ojczyźniana i jest umieszczona nad głową żołnierza. Bohater plakatu ma przypięte ordery, wśród nich szczególnie ceniony order Bohatera Zwiazku Radzieckiego. Ordery państwowe są często przedstawiane na plakatach wojennych, obrazujących męstwo i poświęcenie żołnierzy.

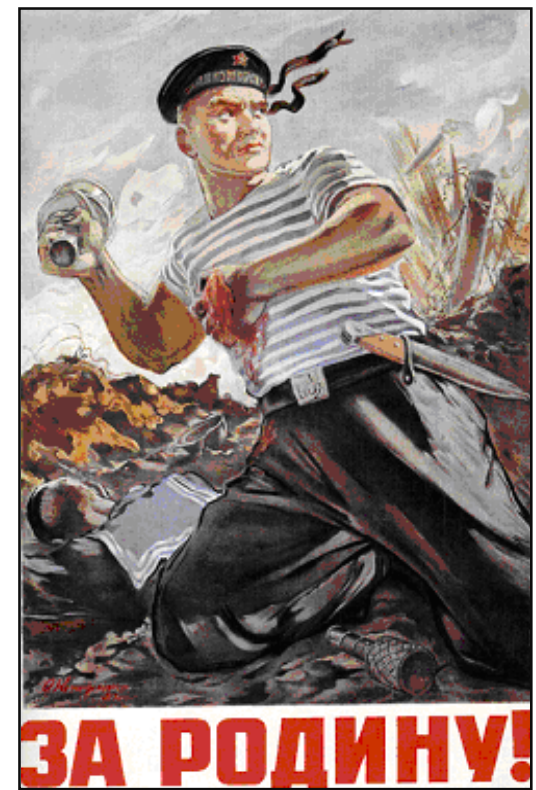

Plakat 21

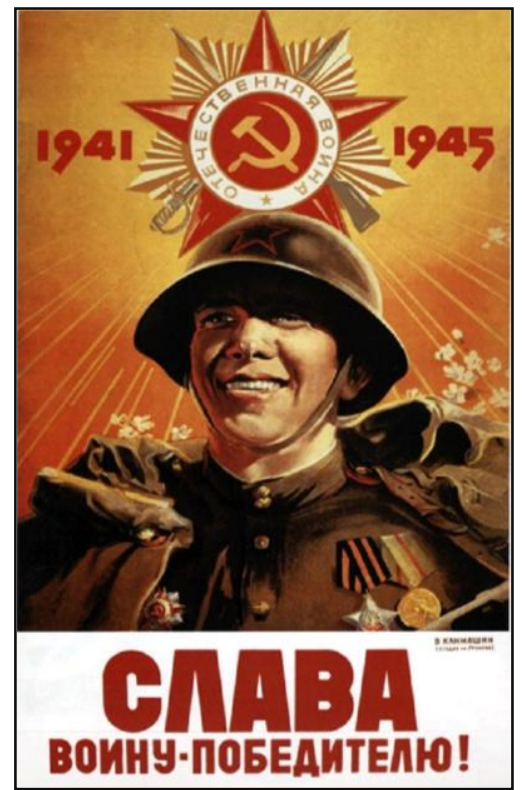

Plakat 22 


\section{4) Obrona ludu rosyjskiego}

Dość liczna grupa sowieckich plakatów wojennych poświęcona była obronie ludności Związku Radzieckiego zagrożonej niemieckim terrorem. Można domniemywać, że głównymi adresatami tych obrazów są obrońcy ojczyzny zarówno ci umundurowani, jak i wszyscy inni stawiający mniej bądź bardziej czynny opór. Przekaz jest jasny: ich los zależy od podejmowanych działań obronnych. Plakaty tej kategorii zawierają głównie podobizny kobiet i dzieci, jako najbardziej bezbronnych i wymagających ochrony. Często na plakatach ukazywano matkę z dzieckiem, postaci uosabiające uświęcone, a zagrożone przez najeźdźcę wartości. Na plakacie 23 dostrzegamy matkę tulącą dziecko w sytuacji śmiertelnego zagrożenia. Na pierwszym planie widać bagnet wrogiego żołnierza, z którego wymownie spływa przelana krew ofiar. Kolejny plakat przedstawia inny prawdopodobny scenariusz, mianowicie niewolę. Na pierwszym planie widać rodzinę zaprzężoną (zamiast zwierzęcia pociągowego) do wozu, którego woźnicą jest hitlerowski żołnierz trzymający $\mathrm{w}$ ręce bat, ponadczasowy symbol zniewolenia. Autor plakatu wskazuje na zbezczeszczone przez niemieckiego najeźdźcę wartości rodzinne. Ponurego wyrazu plakatu dopełniają użyte w nim ciemne barwy.

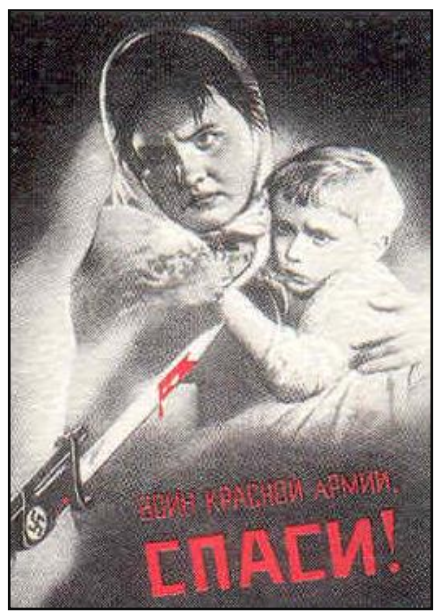

Plakat 23

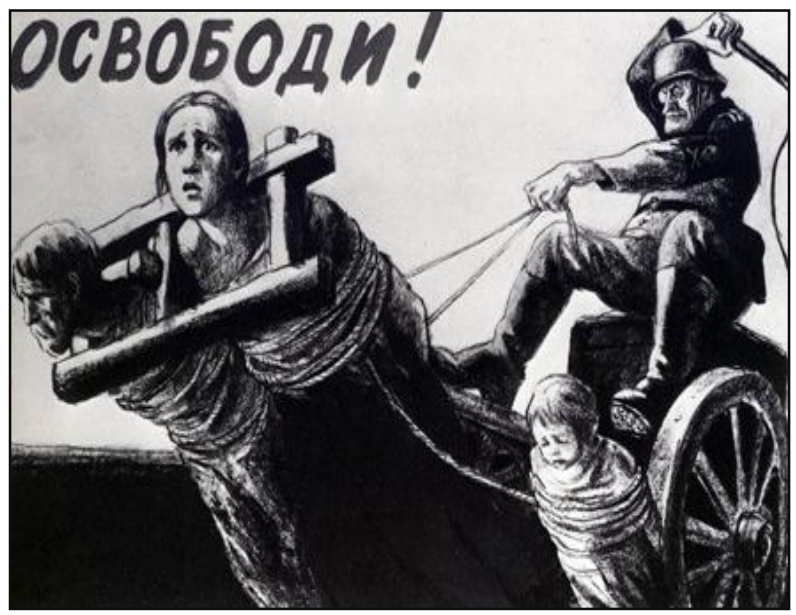

Plakat 24

Warto zauważyć, że radziecka armia składała się głównie z młodych mężczyzn, pochodzących z obszarów wiejskich. Plakaty skierowane do tego odbiorcy podkreślają tradycyjne wartości, takie jak: rodzina, macie- 
rzyństwo, potomstwo itd. Anonimowe ofiary wojny w raportach są ujmowane $\mathrm{w}$ postaci zestawień statystycznych, na plakatach mają zaś postać matki, dziewczyny, rodziny bądź małego dziecka. Są to osoby dobrze znane adresatom przekazu. Na plakacie 25 widzimy młoda, atrakcyjną dziewczynę spętaną drutem kolczastym. Jest to sugestywna przenośnia wyrażająca los, jaki spotka pozostawione na pastwę nieprzyjaciela kobiety. Dziewczyna z plakatu jest częściowo roznegliżowana, co wskazuje na to, że doświadczyła gwałtu lub doświadczy go w przyszłości, o czym świadczy opis zamieszczony na plakacie. Drut kolczasty, jakim jest spętana, sugeruje jej bezbronność w obliczu okrucieństwa. Niemoc ofiar jest także ukazana w kolejnym plakacie (26), przedstawiającym uratowane przez żołnierza dziecko. Podpis pod posterem stanowi jasny przekaz odnośnie do tego, kto zagraża sowieckim dzieciom. Sielankowy obraz plakatu podkreśla rolę Armii Czerwonej w ratowaniu kraju przed zgubą z rąk hitlerowców (prawy dolny róg).

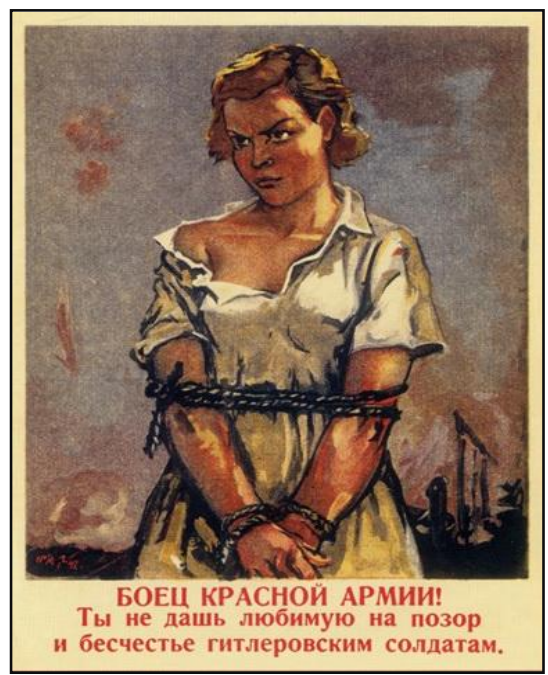

Plakat 25

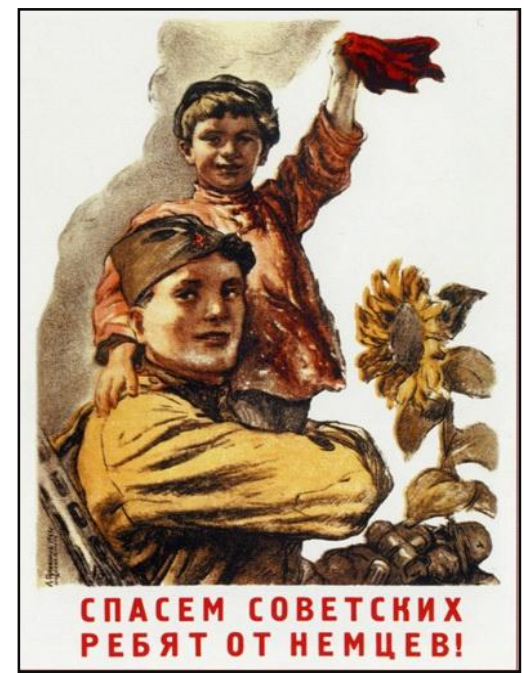

Plakat 26

\section{5) Ojczyzna (Matka Rosja)}

Na uwagę zasługują także plakaty symbolizujące ojczyznę. Na większości z nich ojczyzna jest kojarzona z kobieta, która wzywa do obrony. Warto $\mathrm{w}$ tym miejscu nadmienić, że sam desygnat nazwy ojczyzna w języku polskim pochodzi od wyrazu "ojciec", natomiast w języku ro- 
syjskim wywodzi się od słowa "matka”, podobnie jak w języku angielskim i niemieckim. Kobieta jest zatem bliższa znaczeniowo ojczyźnie niż mężczyzna. Plakat 27 przedstawia dojrzałą kobietę, która dowodzi uniesioną do góry ręką. W drugiej ręce trzyma dokument przysięgi wojskowej, zobowiązującej do obrony zagrożonej ojczyzny. Za jej plecami widać bagnety gotowe do użycia. Plakat wyraźnie apeluje do poczucia obowiązku i honoru adresatów przekazu. Plakat 28 ukazuje ojczyznę pod postacią matki z dzieckiem, okrytych, podobnie jak poprzednio, czerwonym materiałem symbolizującym barwy narodowe. Niżej znajdują się żołnierze różnych formacji i narodowości, którzy walczą w obronie kraju. W intencji autora plakatu walka o wspólne dobro powinna wygrać z partykularnymi interesami, które istniały wcześniej, a nasiliły się po ataku III Rzeszy na Związek Radziecki. W podobnym klimacie utrzymany jest plakat 29 przedstawiający kobietę z kłosami zboża i bronią. Ojczyzna, która karmi, w tej chwili wzywa do broni i żąda zwycięstwa. Plakat ten nasuwa wyraźne skojarzenia $\mathrm{z}$ wizją chłopa $\mathrm{w}$ historii polskich ruchów wyzwoleńczych i hasłem Żywia y bronia.

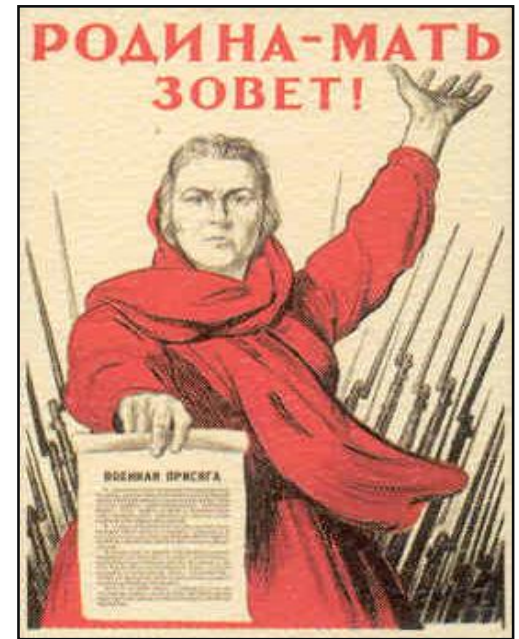

Plakat 27

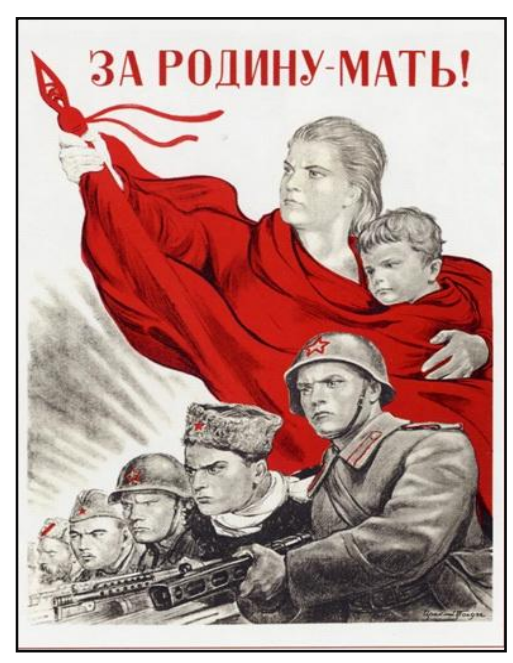

Plakat 28

Plakat 30 utrzymany jest w innym tonie. Tutaj ojczyznę symbolizuje pomnik cenionego i słynnego rosyjskiego poety, Aleksandra Puszkina. Plakat odwołuje się do wielkości rosyjskiej literatury i tradycji. Puszkin zdaje się patrzeć z wysokości na maszerujących żołnierzy, którzy idą bronić ojczyzny. 


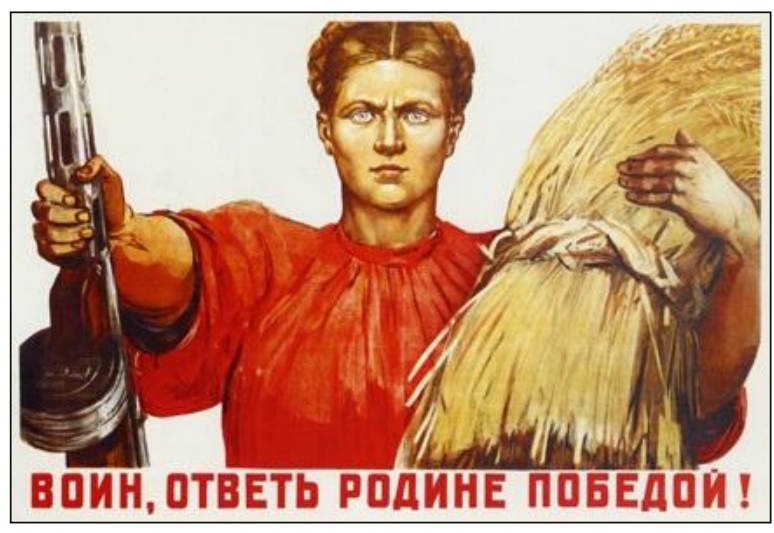

Plakat 29

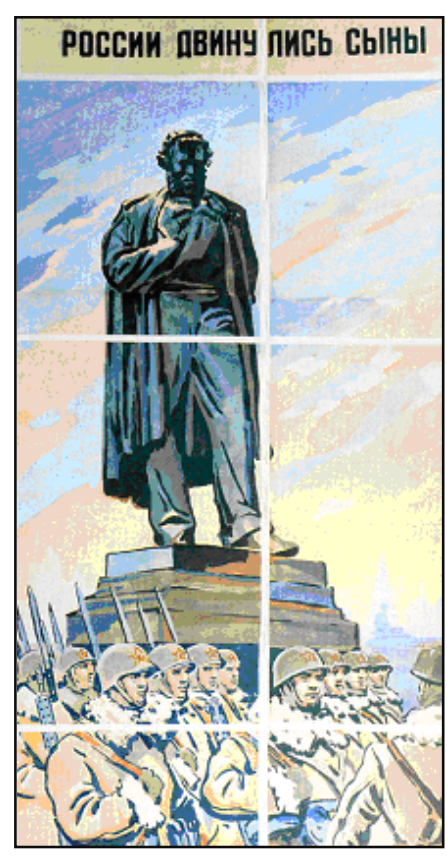

Plakat 30

Zaprezentowane wyżej plakaty, przedstawiające postać dojrzałej kobiety, pozwalają na sformułowanie jeszcze jednej uwagi. Nasuwają one skojarzenia z jungowskim archetypem Wielkiej Matki i związanymi z nim wyobrażeniami archetypowymi ${ }^{6}$, przywodzącymi na myśl ojczyznę jako naturę, duchową matkę, opiekunkę itd. (Pascal 1992; Wehr 1998). Relacja łącząca obrońców oraz bronioną ojczyznę przypomina relację dzieci i Matki. Jest to relacja trwała, silna i osobista. W tym miejscu warto wspomnieć także o powojennych plakatach radzieckich przedstawiających Józefa Stalina, w którym możemy się dopatrywać innego jungowskiego archetypu, mianowicie Wielkiego Mędrca. Stalin jest przedstawiany jako mąż opatrznościowy, ojciec, opiekun, przewodnik duchowy.

${ }^{6}$ Rozróżnienie pomiędzy archetypem i wyobrażeniem archetypowym jest w koncepcji Junga istotne. Jak zaznacza Wehr (1998: 51) „trzeba rozróżnić między »archetypem « a »wyobrażeniami archetypowymi«. Archetyp jako taki przedstawia hipotetyczny, nieoglądowy wzór, jaki znamy w biologii »pattern behaviour«. Można więc powiedzieć całkowicie $w$ duchu Junga: niepoznawalne archetypy są przyczyną powstawania »wyobrażeń archetypowych «". 


\section{6) Militarne wsparcie cywili}

Osobną grupę stanowią plakaty nawołujące do powszechnej, militarnej mobilizacji i obrony kraju przed wrogiem. U podstaw decyzji o emisji niniejszych treści leżała ówczesna sytuacja polityczno-militarna. Jak już wspomniałem wcześniej, atak III Rzeszy na ZSRR stanowił zaskoczenie dla władz państwa i w obliczu aktualnych problemów gospodarczych oraz obronnych niemiecka koncepcja wojny błyskawicznej (Blitzkrieg) odnosiła efekty. Wojska niemieckie, napotykając niewielki opór źle zorganizowanych i słabo wyposażonych oddziałów radzieckich, zaczęły bezpośrednio zagrażać przynajmniej europejskiej części Związku Radzieckiego. W tych okolicznościach zaistniała paląca potrzeba powszechnej mobilizacji wojskowej tych wszystkich, którzy byli w stanie w jakikolwiek sposób stawić opór Wehrmachtowi. W konsekwencji działania propagandowe nabrały charakteru rekrutacji do oddziałów partyzanckich lub innych form aktywnej obrony kraju.

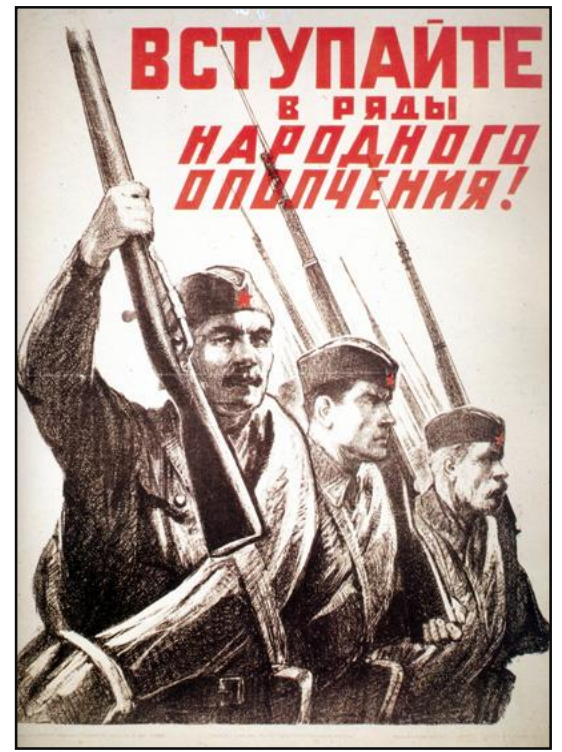

Plakat 31

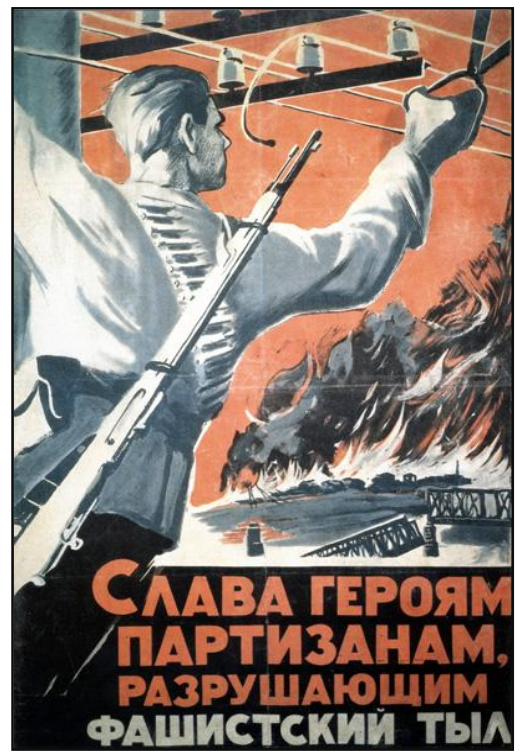

Plakat 32

Plakat 31 nawołuje do pospolitego ruszenia. Na obrazie widzimy jedynie trzech mężczyzn, lecz możemy się domyślać, że ochotników jest znacznie więcej, o czym świadczy liczna broń zaprezentowana w tle. 
Przedstawieni mężczyźni są w sile wieku, co kojarzy się z pospolitym ruszeniem. $Z$ drugiej jednak strony bohaterowie plakatu ubrani są $\mathrm{w}$ uniformy wojskowe i ustawieni w szereg, co może sugerować pełną gotowość do walki i odparcia ataku wroga. Gdy spojrzymy na ich mimikę, widzimy zdecydowanie i upór, widoczne atrybuty obrońców kraju. Podpis na plakacie wraz z formą wykrzyknikową przywodzi raczej na myśl formę rozkazu wojskowego niż zachęty, co zdradza przymus i konieczność spełnienia obowiązku wobec ojczyzny. Plakat obok przedstawia z kolei partyzantów w trakcie dokonywania działań dywersyjnych. $\mathrm{Na}$ pierwszym planie widzimy mężczyznę niszczącego infrastrukturę komunikacyjną - jest $\mathrm{w}$ trakcie przecinania kabla telefonicznego. $\mathrm{W}$ dalszej perspektywie widać wysadzony most kolejowy, w tle zaś płonące zabudowania. Wszystkie te działania są efektem aktywnej, choć skrycie podejmowanej, obrony państwa. Stanowią unaoczniony wzór do naśladowania.

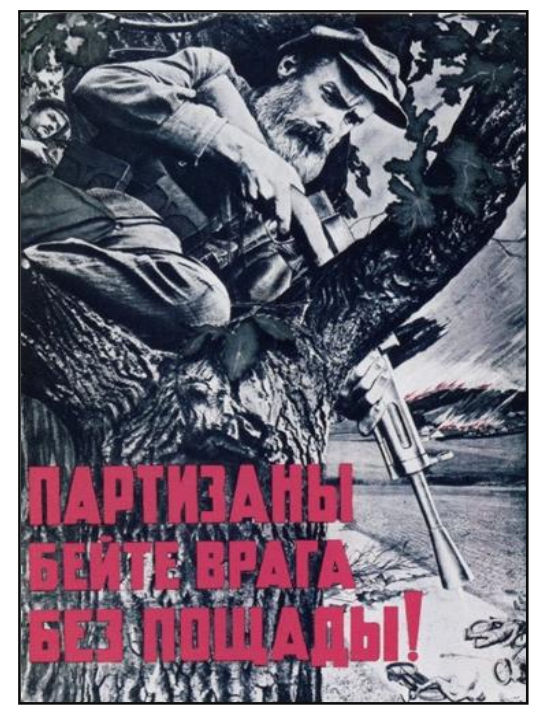

Plakat 33

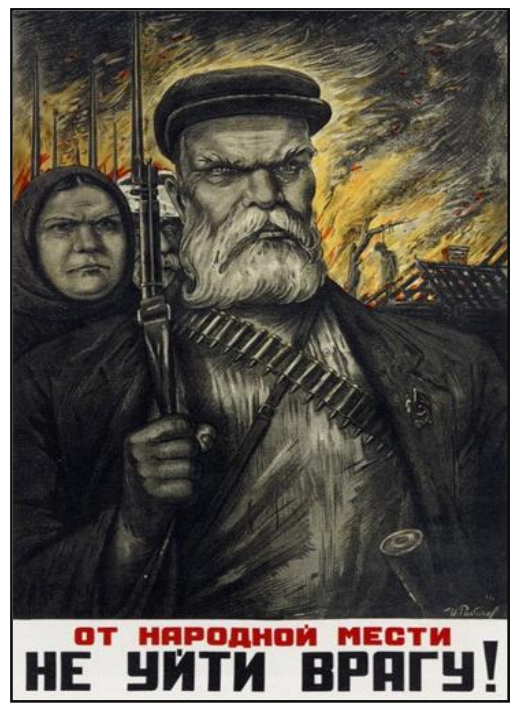

Plakat 34

Partyzant $\mathrm{w}$ trakcie prowadzenia działań obronnych jest przedstawiony także na plakacie 33. Warto zauważyć, że jest to człowiek w znacznie bardziej zaawansowanym wieku, niż postacie na poprzednich plakatach, co czyni przekaz bardziej uniwersalnym: każdy może i powinien służyć ojczyźnie. Mężczyzna siedzi na drzewie i czeka na wroga w pozycji snajperskiej. Realizmu dodaje plakatowi utrzymanie go w formie foto- 
grafii, co wskazuje na to, że jesteśmy świadkami wydarzenia, do którego rzeczywiście doszło. Jeszcze bardziej uniwersalny jest charakter przekazu plakatu 34. Widzimy na nim starców, którzy bronią ojczyzny. W tle widać pożar, którego źródeł możemy się domyślać po sylwetkach wisielców. Prawdopodobnie stanowi on rezultat działań armii hitlerowskiej. Geneza pożaru tłumaczyłaby surowe, a wręcz wrogie oblicza postaci na posterze. Starsi ludzie, bardziej kojarzeni z ofiarami wojen, tutaj są przedstawieni jako mściciele - partyzanci. Ich gniew przekłada się na aktywne działanie - obronę ojczyzny. Świadczy o tym ich uzbrojenie: broń palna, amunicja i granat.

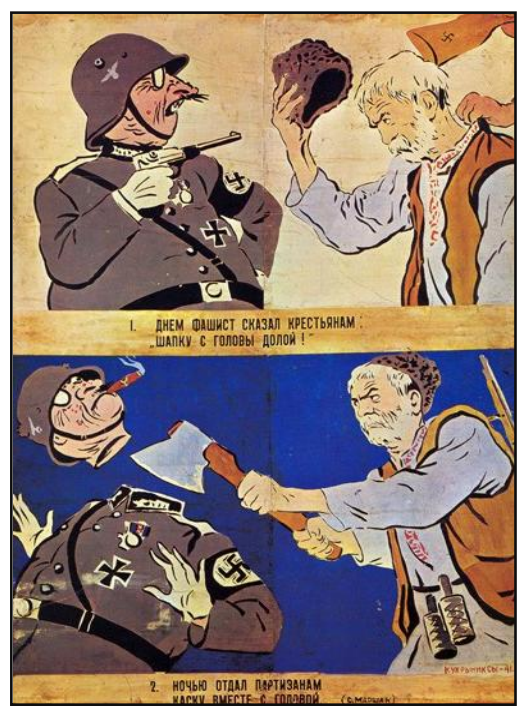

Plakat 35

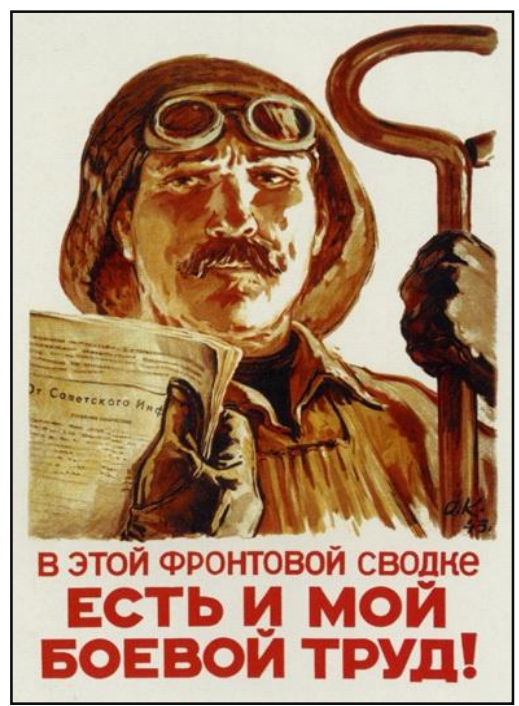

Plakat 36

Plakat 35 w ciekawy sposób przedstawia istotę działań partyzanckich. Partyzanci za dnia nie rzucają się w oczy, są ulegli i spolegliwi, są to jednak pozory, gdyż pod osłoną nocy stają się zabójczy. Jest to postawa typowa wobec dobrze uzbrojonego wroga, który poczuł się zbyt pewny siebie. Postać Niemca jest otyła. W obliczu zaskoczenia on sam okazuje się nieporadny. Traci życie z rąk tego samego chłopa, którego wcześniej upokarzał. W innym klimacie utrzymany jest plakat 36, który prezentuje dokonania partyzanta w zakresie obrony kraju. Tak ma prawo poczuć się każdy, kto w sposób aktywny zaangażował się w walkę z wrogiem. Plakat jest zwiastunem przyszłej nagrody, jaka czeka tych wszystkich, którzy podjęli walkę. 


\section{7) Środki ostrożności}

Kolejna seria plakatów poświęcona jest zachowaniu ostrożności w kontaktach z innymi, którzy mogą okazać się wrogami. Z plakatów płynie przekaz, że nieprzyjaciel jest wszędzie, choć może przybrać postać niewinną lub taka, której nie definiujemy w kategoriach zagrożenia. Nie wiemy, jak dokładnie wróg może wyglądać, dlatego należy podejrzewać każdego. Ostrożność jest konieczna i powinna stać się nawykiem.

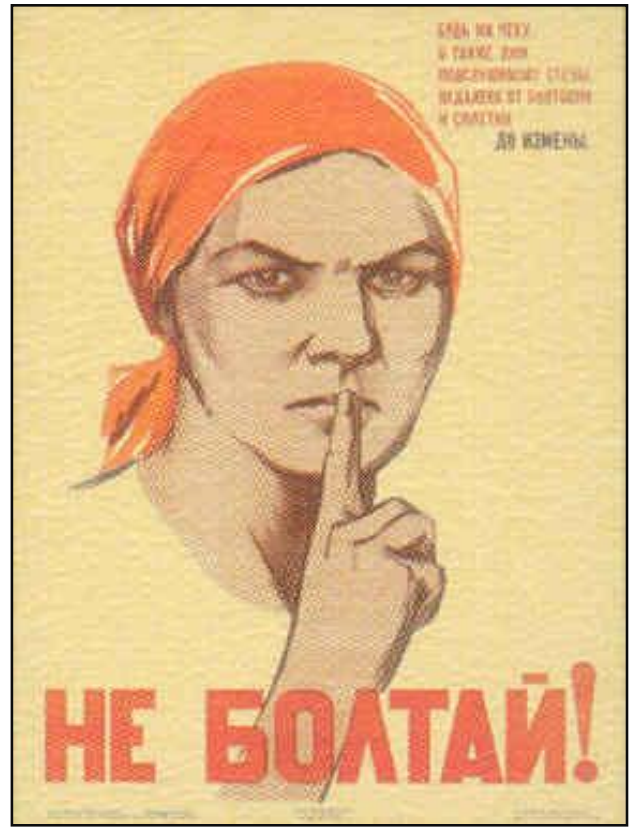

Plakat 37

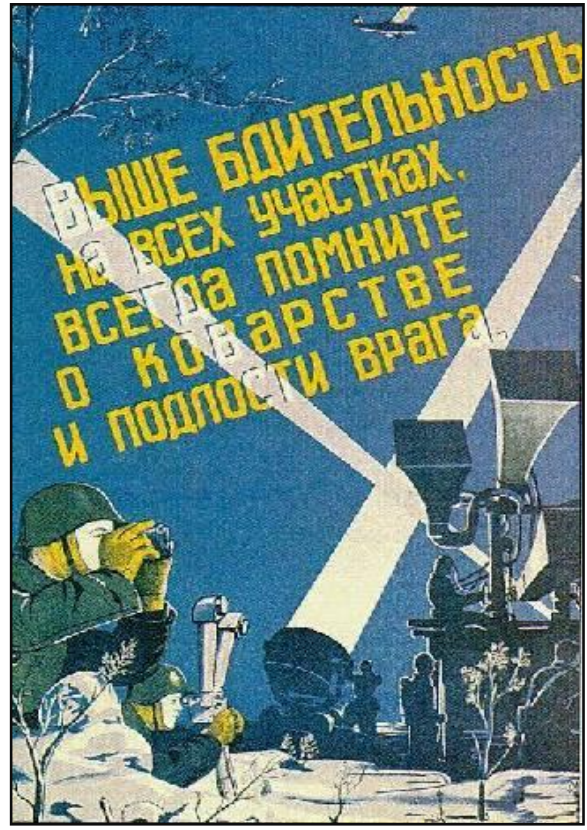

Plakat 38

Do ostrożności, czyli w tym przypadku powstrzymywania się od gadulstwa, nawołuje plakat 37. Widzimy na nim "typową" kobietę z chustą na głowie. Niczym się ona nie wyróżnia, gdyż intencją autora plakatu jest wskazanie na to, że niebezpieczne mogą być nawet zwykłe, codzienne rozmowy. Kobieta z plakatu przestrzega nas przed nieostrożnymi kontaktami, których treść może być wykorzystana przez wroga. Plakat 38 utrzymany jest $\mathrm{w}$ innym tonie. Jego adresatami są żołnierze, którzy powinni zachować „najwyższą ostrożność”. Na obrazie widzimy wojskowych wypatrujących przez lornety wroga. Wprawdzie go nie widać, ale nie zwalnia to ich z obowiązku zachowania ostrożności, gdyż 
„wróg jest podstępny i podły”, więc może nadejść niespodziewanie. Żołnierze na plakacie wyczekują wroga w nocy, są czujni i stanowią przykład do naśladowania.

Na kolejnych plakatach (39 i 40) wróg został pokazany i zdemaskowany. W każdym z przypadków jego wygląd zdecydowanie przeczy stereotypom. Oba plakaty pochodzą z roku 1945, są więc skierowane do żołnierzy, którzy wyzwalają inne kraje i nie przebywają na swoim terytorium, w związku z czym mogą być bardziej podatni na operacje planowane przez przebiegłego wroga. Na pierwszym z nich ma on postać przysłowiowego „wilka w owczej skórze”. Plakaciści dość chętnie nawiązują do ludowych powiedzeń i przysłów, które mogą tutaj znaleźć zastosowanie. Żołnierz z tego plakatu, podobnie jak z kolejnego, jest czujny, zdemaskował wroga. Plakat 40 ukazuje marynarza, który pojmał wrogiego żołnierza w przebraniu. Pod nierzucającym się w oczy płaszczem skrywa się wróg, który jest podstępnym dywersantem. W ręku trzyma zapaloną pochodnię, u boku zaś ma granat. Nie walczy w sposób jawny, trudniej więc go wykryć. Oba plakaty nawiązują do faktu, że w momencie, gdy przegrana III Rzeszy była już przesądzona wielu żołnierzy, zwłaszcza formacji uznanych za szczególnie zbrodnicze (SS, SD, Gestapo itd.), zmieniało tożsamość, próbując wydostać się z okrążenia. Plakaty nawołują więc do utrzymania czujności wobec pojmanych jeńców.

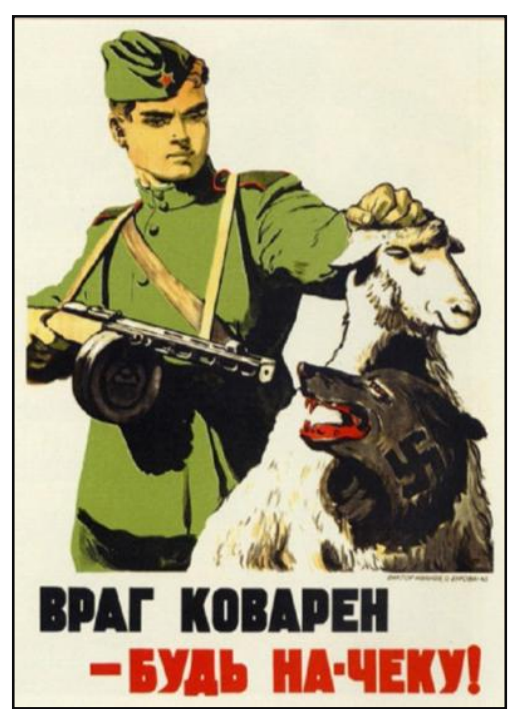

Plakat 39

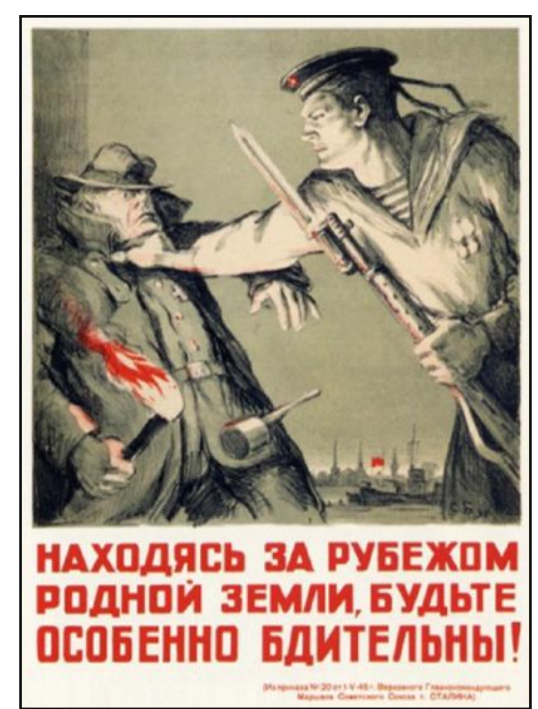

Plakat 40 
Warto $\mathrm{w}$ tym miejscu nadmienić, że plakaty ukazujące szpiegów i dywersantów odzwierciedlają dość powszechną obsesję wzajemnej kontroli i nieustannej czujności, wpisanej w sowiecką tradycję nie tylko okresu wojennego (Sołżenicyn 1998). Plakaty nawiązujące do tropienia szpiega, bumelanta, wroga ludu itd., z akcentem rozłożonym w zależności od bieżącej sytuacji w kraju, występowały powszechnie w okresie konfliktu, lecz także w czasie pokoju.

\section{8) Wsparcie cywili o charakterze niemilitarnym}

Duża część plakatów emitowanych w czasie wojny była poświęcona zachęcaniu do pracy na rzecz wzrostu gospodarczego, a w związku z tym także zwiększania militarnej siły ZSRR. Adresatami tych przekazów byli przede wszystkim robotnicy i chłopi, którzy poprzez produkcję przemysłową i rolną umożliwiali odbudowę zniszczeń wojennych i kontynuację obrony, a później podjęcie ofensywy.

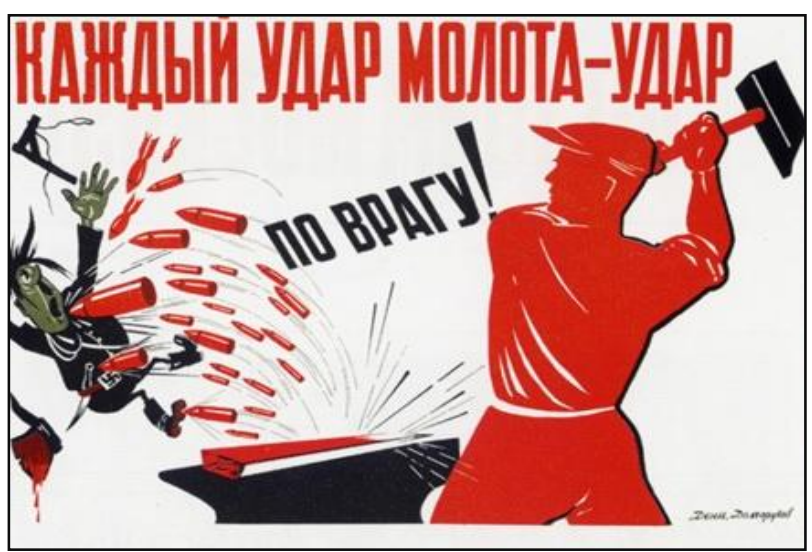

Plakat 41

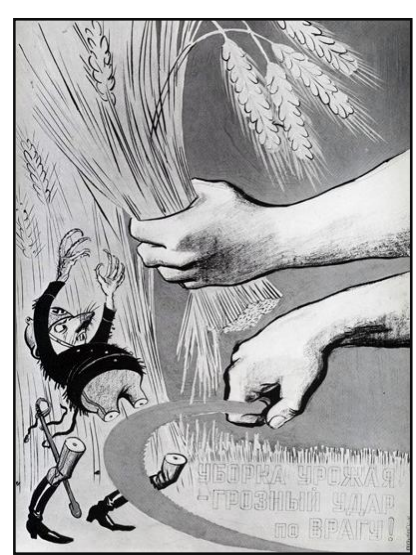

Plakat 42

Plakat 41 skierowany jest do klasy robotniczej. Na posterze widzimy kowala, który uderzeniem młota przekształca metal w pociski. Plakat przedstawia pracę $\mathrm{w}$ połączeniu $\mathrm{z}$ jej natychmiastowymi efektami. Robotnicy mogą zauważyć, że to, w jaki sposób pracują ma znaczenie dla obrony kraju i zwyciężenia wroga. Na plakacie wróg ma twarz Hitlera kata, który raniony pociskami nie będzie już robił użytku z narzędzi trzymanych w rękach - topora ociekającego krwią i szubienicy. Kolejny plakat jest zaadresowany do chłopów. Przekaz jest jasny - zbierając plo- 
ny i dostarczając żywność tym, którzy walczą, bezpośrednio przyczyniamy się do klęski wroga. Emisja plakatów tego rodzaju wiązała się z niechęcią chłopstwa do wypełniania wygórowanych kontyngentów żywności, która niejednokrotnie była odbierana siłą. Poza tym masy chłopskie stanowiły najmniej uświadomioną politycznie i zaangażowaną warstwę ludności.

Adresatkami plakatów wzywających do pracy na rzecz obronności kraju były także kobiety. Na plakacie 43 widzimy jedną z robotnic fabryki uzbrojenia. Kobieta wykonuje prace stereotypowo kojarzone raczej z męskimi zajęciami, które wymagają większej wytrzymałości i siły. Przekaz plakacisty jest jasny: kobiety ze Związku Radzieckiego staną na wysokości zadania także i w tym przypadku. Plakat odpowiadał ówczesnej sytuacji społecznej, w której większość mężczyzn powołana do aktywnej obrony ojczyzny nie mogła wykonywać pracy w fabrykach. W ich miejsce rekrutowano kobiety, które w dużej mierze dźwigały gospodarczy ciężar wojny. Kobieta z plakatu dumnie trzyma rękę na wyprodukowanym przez siebie pocisku. Jest on "darem” dla walczących. Warto tu wspomnieć, że kobiety pojawiały się dość często na plakatach wojennych. W zależności od rodzaju przekazu i intencji autora stanowiły one albo przykład do naśladowania dla innych kobiet, albo były ukazywane jako ofiary wojny bądź też symbolizowały ojczyznę. Kolejny plakat przedstawia zbiorowy wysiłek robotników pracujących na Uralu w zakładach przemysłu ciężkiego. Podobnie jak w przypadku plakatów 41 i 42 efekt pracy jest natychmiastowy - wyprodukowana stal posłuży do walki z wrogiem.

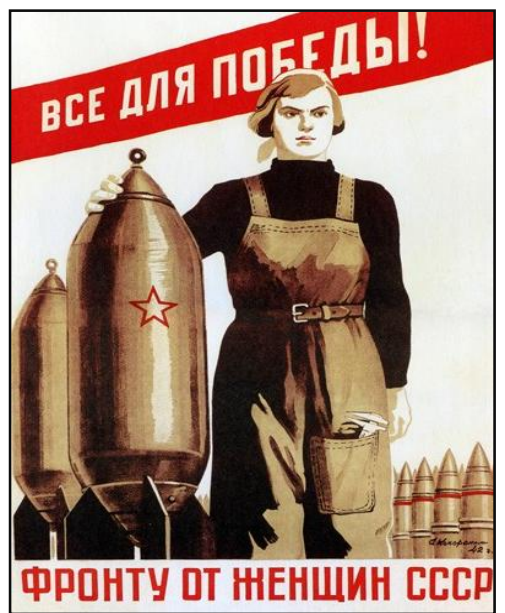

Plakat 43

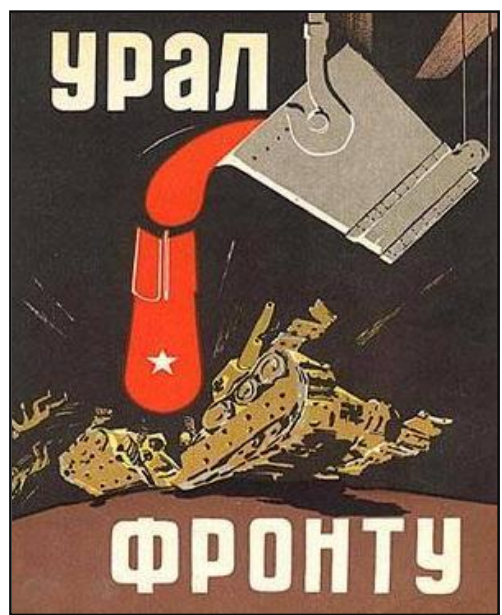

Plakat 44 


\section{9) Historia}

Dość liczna grupa plakatów odnosi się do wydarzeń historycznych. Chwalebne czyny są powodem do dumy i wzmożenia działań obronnych. Autorzy plakatów prezentują dawnych bohaterów i ich wysiłki, które muszą być powtórzone teraz, gdy ojczyzna ponownie jest w niebezpieczeństwie. Dawni herosi często są przedstawieni jako widma stanowiące tło dla aktualnie walczących żołnierzy. Dystans czasowy przekłada się na dystans przestrzenny. Plakat 45 przedstawia zbrojnych mężów epoki wojen średniowiecznych, podczas gdy na pierwszym planie znajdują się współcześni wojownicy. Napis na plakacie nawołuje do męstwa i poświęcenia, także życia, w obronie ojczyzny. W nieco innym klimacie utrzymany jest plakat 46, w którym mamy do czynienia z kilkoma pokoleniami bohaterów, takich jak Suworow (Aleksandr Wasiljewicz Suworow, XVIII-wieczny rosyjski dowódca wojskowy) czy Czapajew (Wasilij Iwanowicz Czapajew, bohater I wojny światowej). Kierując się ich przykładem i obrosłymi legendą czynami, żołnierze Armii Czerwonej bohatersko stawiają czoła wrogowi. Żołnierze, podobnie jak ich wielcy mentorzy przodkowie, są ukazani w sytuacji natarcia, co zwiększa dynamizm przekazu. Na plakacie także widać, że pomimo faktu, iż wraz z wyraźnym rozwojem techniki wojskowej zmienił się oręż, nie zmienił się jednak duch walki i determinacja w obronie ojczyzny (Bullock 1991: 212).

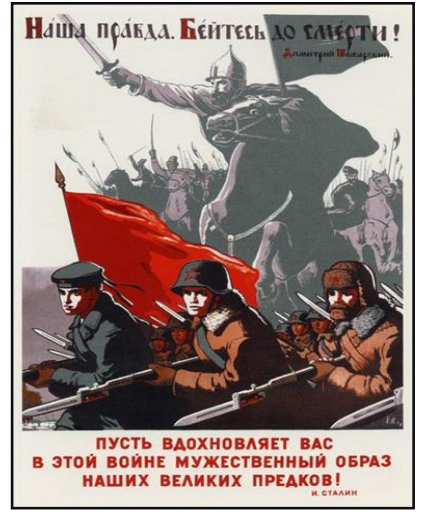

Plakat 45

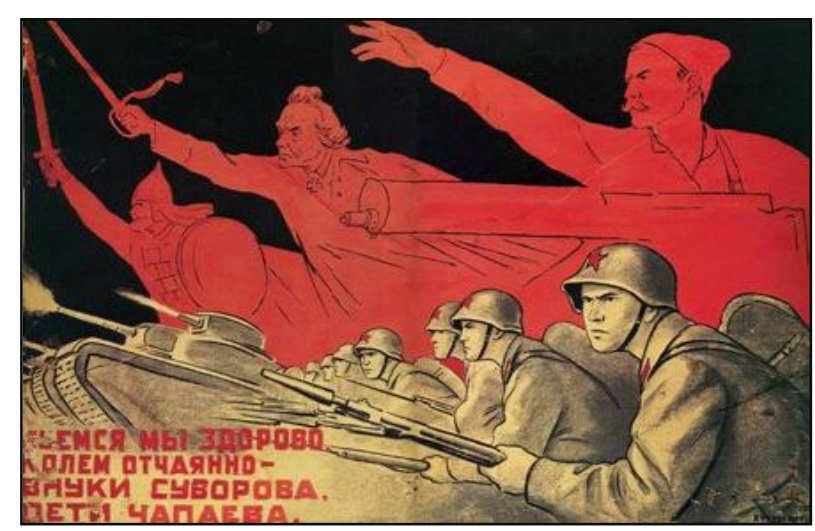

Plakat 46

Plakaty akcentujące historię często odnoszą się do postaci Napoleona Bonaparte. Napoleon jest wykorzystywany przez plakacistów jako przykład najeźdźcy, który pomimo dysponowania dobrze wyszkoloną i liczną 
armią przegrał z Rosją. Przykład ten jest szczególnie ważny teraz, gdy sytuacja, choć $\mathrm{w}$ innych okolicznościach, powtarza się. Plakat 47 wskazuje na dwóch agresorów - Napoleona i Hitlera. Zauważmy, że Napoleon jest większy i bardziej groźny, Hitler zaś wydaje się przy nim karłem, jego karykatura, na co wskazywać może podobne nakrycie głowy. Przekaz plakatu jest klarowny: skoro udało się zwyciężyć Napoleona, uda się to także w przypadku Hitlera, który stanowi mniejsze zagrożenie. Plakat wskazuje, że Hitler jest zarozumiały, czyli przecenia swoje możliwości, nie jest tak niebezpieczny, jak mogłoby się to pozornie zdawać.

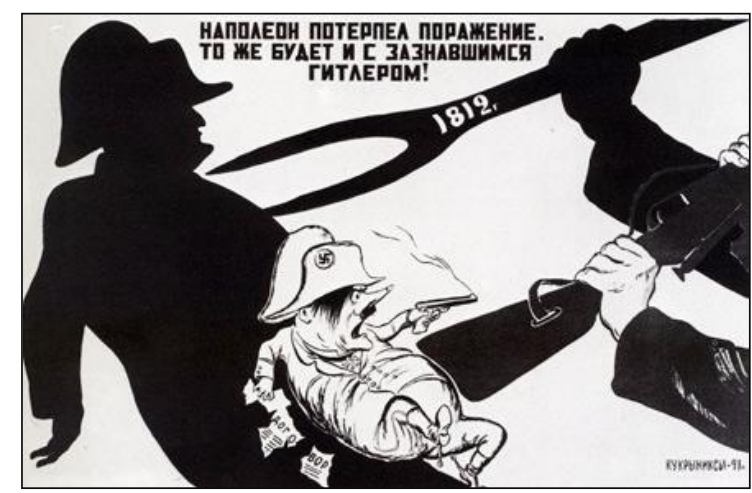

Plakat 47

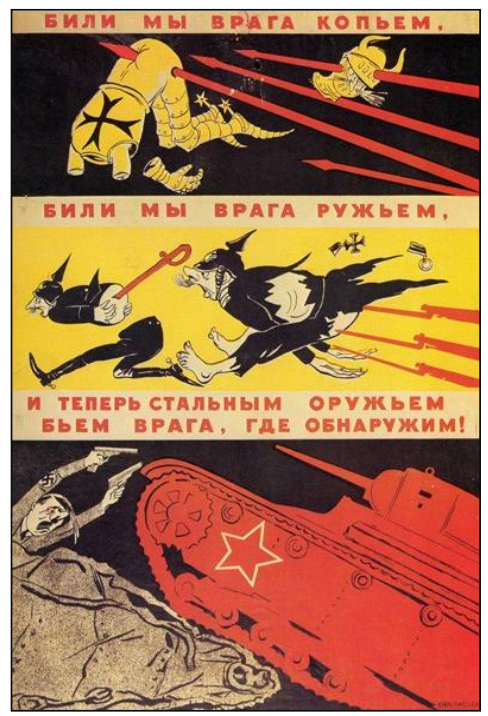

Plakat 48 


\section{Zakończenie i podsumowanie}

Opisane w niniejszej pracy plakaty stanowią jedynie niewielką część tych, które pojawiły się w czasie wielkiej wojny ojczyźnianej, czyli w latach 1941-1945. Nie można także mówić o "reprezentatywności” przedstawionego tutaj materiału. Kierując się jedynie częstotliwością występowania określonych motywów, treści, symboliki, dokonałem wyodrębnienia kategorii ilustrowanych obrazami, które, w moim przekonaniu, najbardziej oddają ich sens. Pomimo niedoskonałości związanych przede wszystkim z brakiem dostępu do pełnej bazy plakatów i koniecznością arbitralnego wyboru tych, które mogę przedstawić w pracy, należy pokusić się o kilka słów podsumowania.

Przede wszystkim warto zwrócić uwagę na perspektywę czasowa, w jakiej dokonuje się analizy plakatów. Ich cel, treść i przesłanie znacznie różną się od siebie $\mathrm{w}$ zależności od tego, jak rozwijała się sytuacja polityczna i militarna. W roku 1941 gros plakatów było ukierunkowanych na wywołanie poczucia obowiązku i solidarności w walce ze wspólnym wrogiem. Odpowiadały one bieżącym problemom wynikającym z silnych tendencji separatystycznych, dostrzegalnych wśród narodów „składających się" na Związek Radziecki. Ponadto komuniści stanowili ciągle „nową władzę", która nie wszędzie była na tyle silna, by wymusić postawę konformistyczną. Zagrożenie dla władzy wiązało się z wkroczeniem wojsk niemieckich, które, jak już nadmieniłem, na pewnych obszarach były witane jako wyzwoliciele. Kontekst czasowy związany $\mathrm{z}$ meandrami wydarzeń wojennych wyrażał się także $\mathrm{w}$ ukazywaniu strachu i zagrożenia podczas intensyfikacji niemieckiej ofensywy w latach 1941-1942, by później ustąpić miejsca akcentowaniu dumy narodowej i propagandy sukcesu $\mathrm{w}$ miarę wypierania wojsk niemieckich. Plakaty ostatniego okresu wojny $\mathrm{w}$ dużej mierze skoncentrowane są na temacie pogoni za cofającymi się siłami wroga. Najmniejszym zmianom podlegały apele, kierowane do ludności cywilnej, o bardziej wydajną pracę na rzecz przemysłu i produkcji rolnej. Związek Radziecki, biorąc na siebie ciężar wiązania znacznej części wojsk niemieckich, odczuwał duże braki w zaopatrzeniu, wyposażeniu wojskowym i w żywność artykuły niezbędne do prowadzenia wojny. To od wzmożonej pracy ludności cywilnej zależała $\mathrm{w}$ dużej mierze obrona kraju, a później ofensywa. 
Ponadto można także zauważyć, że radzieckie plakaty okresu wielkiej wojny ojczyźnianej są w przeważającej mierze zdecydowanie nacechowane emocjonalnie. Plakaciści stosują cały wachlarz środków mających wywołać emocje - od strachu, złości, nienawiści, poprzez chęć odwetu, uwielbienia, wdzięczności i oddania. Warto tu nadmienić, że autorzy plakatów koncentrowali się nie tylko na wywołaniu pożądanych emocji, lecz także kojarzyli je z obiektem, który inicjował właściwe działanie, korespondujące z określoną emocją. Niekiedy plakaty jedynie kanalizowały emocje podzielane kolektywnie, a wywołane powszechnie znanym zdarzeniem, jak np. oblężenie Stalingradu lub okrucieństwo wojsk niemieckich.

Trzeba także wspomnieć, że dla odbiorcy nie pozostawia się marginesu swobody interpretacyjnej, gdyż rzeczywistość ukazana przez plakat ma charakter bipolarny, jest czarna lub biała. Plakaciści wykazywali tendencję do manicheistycznej wizji świata, w którym wybór dobrej i złej strony był prosty i oczywisty dla każdego, bez względu na wiek, płeć, pochodzenie społeczne czy wykształcenie. Możemy więc tutaj mówić o homogenizacji przekazu plakatowego, która objawiała się w założeniu prostoty treści i łatwości odczytywania intencji twórcy. Skuteczny plakat to taki, który nie nastręcza trudności interpretacyjnych, lecz kształtuje postawy obywateli. $\mathrm{W}$ tej dziedzinie $\mathrm{z}$ doświadczenia radzieckich plakacistów korzystali chociażby hiszpańscy komuniści w okresie hiszpańskiej wojny domowej (patrz tekst M. Melnyk).

\section{Bibliografia}

Aronson, E., Wilson, T. D., Akert, R. M., (1997), Psychologia społeczna - serce $i$ umyst, thum. A. Bezwińska i in. Poznań: Wydawnictwo Zysk i S-ka.

Bullock, A., (1991), Hitler i Stalin - żywoty równoległe, tłum. M. Lipska, J. Mianowski, M. Rudowski. Warszawa: Dom Wydawniczy Bellona.

Cialdini, R., (2007), Wywieranie wptywu na ludzi: teoria i praktyka, tłum. B. Wojciszke. Gdańsk: Gdańskie Wydawnictwo Psychologiczne.

Dominiak, Ł., (2003), Diabet na Sołowkach, czyli śmierć wrogom ludu, „Dialogi Polityczne” nr 1 (luty), http://www.dialogi.umk.pl/archiwum/1/02_dominiak.pdf

Ferenc, T., (2007), Analiza obrazów - przegląd metod i inspiracji teoretycznych, „Folia Sociologica", t. 32, nr 27: 5-26.

Frąckowiak, M., (2008), Zdjęcie jako rebus. Zastosowanie wywiadu fotograficznego na przykładzie badań "Pornografialerotyka: pytanie o kontekst czy estetyke??", [w:] J. Kaczmarek (red.), Do zobaczenia. Socjologia wizualna w praktyce badawczej. Poznań: Wydawnictwo Naukowe UAM. 
Goffman, E., (1979), Gender Advertisements. New York-Hagerstown-San Francisco- London: Harper \& Row Publishers.

Kershaw, I., (2001), Hitler. 1889-1936. Poznań: Hybris, Rebis.

Konecki, K. T., (2005), Wizualne wyobrażenia. Główne strategie badawcze w socjologii wizualnej a metodologia teorii ugruntowanej, „Przegląd Socjologii Jakościowej”, vol. I, nr 1.

Lyons, J., (1989), Semantyka, t. 1, Warszawa: PWN.

Pascal, E., (1992), Psychologia jungowska. Poznań: Wydawnictwo Zysk i S-ka.

Rose, G., (2006), Visual methodologies. London-Thousand Oaks-New Delhi: Sage Publications Inc.

Sołżenicyn, A., (1998), Archipelag Gułag 1918-1956. Próba dociekania literackiego. Warszawa: Świat Książki.

Stańczak, G. G., (2007), Visual Research Methods. Image, Society and Represenations. Los Angeles-London-New Delhi-Singapore: Sage Publications Inc.

Strauss, A. L., Corbin, J., (1990), Basics of Qualitative Research. Grounded Theory. Procedures and Techniques. California: SAGE Publications.

Tesar, J. E., Doppen, F. H., (2007), Propaganda and collective behavior: Who is doing it, how does it affect us, and what can we do about it? „The Social Studies”, 97 (6): 256-261.

Wehr, H., (1998), Carl Gustav Jung. Wrocław: Wydawnictwo Dolnośląskie.

http://eng.plakaty.ru/

http://www.globalissues.org/article/157/war-propaganda-and-the-media

http://www.rosjapl.info/rosja/plakat_wojna.php

http://www.zmag.org/zspace/commentaries/1477

\section{Informacje na temat wykorzystanych w pracy plakatów}

\section{Plakat 1}

Autor: Kukryniksy (właśc. М. В. Куприянов, П. Н. Крылов, Н. А. Соколов), 1941

Tytuł: Kleszcze w kleszcze

Źródło: http://eng.plakaty.ru

\section{Plakat 2}

Autor:, Kukryniksy, 1941

Tytuł: Bezlitośnie rozgromimy i zlikwidujemy wroga

Źródło: http://eng.plakaty.ru

\section{Plakat 3}

Autor: Kukryniksy, 1941

Tytuł: Ludojad - wegetarianin. Dwie strony medalu

Źródło: http://eng.plakaty.ru

\section{Plakat 4}

Autor: Viktor Nikolaevich Denisov, 1941

Tytuł: Na Moskwę! Z Moskwy!

Źródło: http://eng.plakaty.ru 


\section{Plakat 5}

Autor: Kukryniksy, 1942

Tytuł: Maszyna do tgania

Źródło: http://eng.plakaty.ru

\section{Plakat 6}

Autor: Kukryniksy, 1942

Tytuł: Dojna krowa

Źródło: http://eng.plakaty.ru

\section{Plakat 7}

Autor: Kukryniksy, 1944

Tytuł: Lekcja Niemcom. Hitler planuje, a Armia Czerwona rozlokowuje się

Źródło: http://eng.plakaty.ru

\section{Plakat 8}

Autor: Kukryniksy, 1944

Tytuł: Na audiencji u opętanego głównodowodzacego

Źródło: http://eng.plakaty.ru

\section{Plakat 9}

Autor: Kukryniksy, 1944

Tytuł: Trzy lata wojny

Źródło: http://eng.plakaty.ru

\section{Plakat 10}

Autor: Kukryniksy, 1944

Tytuł: Ostatni numer programu

Źródło: http://eng.plakaty.ru

\section{Plakat 11}

Autor: Kukryniksy, 1941

Źródło: http://eng.plakaty.ru

\section{Plakat 12}

Autor: Viktor Nikolaevich Denisov, Nikolay Andreevich Dolgorukov, 1942

Tytuł: Stalingrad

Źródło: http://eng.plakaty.ru

\section{Plakat 13}

Autor: Kukryniksy, 1942

Tytuł: Młody Fritz

Źródło: http://eng.plakaty.ru

\section{Plakat 14}

Autor: Kukryniksy, 1942

Tytuł: Transformacja "Fritzów"

Źródło: http://eng.plakaty.ru

\section{Plakat 15}

Autor: Leonid Fedorovich Golovanov, 1942

Źródło: http://eng.plakaty.ru 
Plakat 16

Autor: Kukryniksy, 1944

Tytuł: Powrót

Źródło: http://eng.plakaty.ru

\section{Plakat 17}

Autor: Mikhail Nikolaevich Avvakumov; V. Scheglov, 1941

Tytuł: Osiagnięć października nie oddamy!

Źródło: http://eng.plakaty.ru

\section{Plakat 18}

Autor: nieznany

Tytuł: Za ojczyznę, za honor, za wolność

Źródło: http://www.rosjapl.info/rosja/plakat_wojna.php

\section{Plakat 19}

Autor: Jurij (Georgij) Nikolaevich Petrov, Vladimir Aleksandrovich Tambi, 1941

Tytuł: Nie będa czarne skrzydła latać nad ojczyzna

Źródło: http://eng.plakaty.ru

\section{Plakat 20}

Autor: Pavel Petrovich Sokolov-Skalja, 1941

Tytuł: Na ziemi i nad ziemia okrą̇ymy wroga

Źródło: http://eng.plakaty.ru

\section{Plakat 21}

Autor: Aleksei Alekseevich Kokorekin, 1943

Tytuł: Za ojczyzne

Źródło: http://eng.plakaty.ru

\section{Plakat 22}

Autor: Viktor Semyonovich Klimashin, 1945

Tytuł: Stawa żotnierzowi-zwycięscy!

Źródło: http://eng.plakaty.ru

\section{Plakat 23}

Autor: Viktor Borisovich Koretskij, 1942

Tytuł: Żotnierzu Armii Czerwonej - ratuj!

Źródło: http://eng.plakaty.ru

\section{Plakat 24}

Autor: Kukryniksy, 1942

Tytuł: Oswobódź!

Źródło: http://eng.plakaty.ru

\section{Plakat 25}

Autor: F. Antonov, 1942

Tytuł: Żotnierzu Armii Czerwonej! Nie wydasz tego, co kochasz na hańbę i zbezczeszczenie hitlerowskim żotnierzom

Źródło: http://eng.plakaty.ru 


\section{Plakat 26}

Autor: Leonid Fedorovich Golovanov, 1943

Tytuł: Uratujmy sowieckie dzieci od Niemców

Źródło: http://eng.plakaty.ru

\section{Plakat 27}

Autor: Iraklij Moiseevich Toidze, 1941

Tytuł: Ojczyzna wzywa!

Źródło: http://eng.plakaty.ru

\section{Plakat 28}

Autor: Iraklij Moiseevich Toidze, 1943

Tytuł: Za ojczyzne

Źródło: http://eng.plakaty.ru

\section{Plakat 29}

Autor: Dementij Alekseevich Shmarinov, 1942

Tytuł: Wojowniku, odpowiedz ojczyźnie zwycięstwem

Źródło: http://eng.plakaty.ru

\section{Plakat 30}

Autor: Pavel Petrovich Sokolov-Skalja, 1942

Tytuł: Synowie Rosji wyruszyli

Źródło: http://eng.plakaty.ru

\section{Plakat 31}

Autor: Aleksej Gumbertovich Sittaro, 1941

Tytuł: Wstęujcie w szeregi pospolitego ruszenia

Źródło: http://eng.plakaty.ru

\section{Plakat 32}

Autor: Pavel Petrovich Gorelyj, 1941

Tytuł: Chwała bohaterskim partyzantom niszczacym faszystowskie odwody

Źródło: http://eng.plakaty.ru

\section{Plakat 33}

Autor: Viktor Borisovich Koretskij, 1941

Tytul: Partyzanci bijcie wroga bez litości

Źródło: http://eng.plakaty.ru

\section{Plakat 34}

Autor: Isaak Ben'evich Rabichev, 1941

Tytuł: Od narodowej zawieruchy nie uciekniesz wrogu

Źródło: http://eng.plakaty.ru

\section{Plakat 35}

Autor: Kukryniksy, 1941

Tytuł: Za dnia faszysta powiedział chłopu: zdejmij czapkę z głowy. Noca oddał partyzantowi głowe razem $z$ hetmem

Źródło: http://eng.plakaty.ru 


\section{Plakat 36}

Autor: Aleksei Alekseevich Kokorekin, 1943

Tytuł: W tym frontowym raporcie sa i moje wojenne dokonania!

Źródło: http://eng.plakaty.ru

\section{Plakat 37}

Autor: Nina Nikolaevna Vatolina, Viktor Nikolaevich Denisov, 1941

Tytuł: Nie gadaj!

Źródło: http://eng.plakaty.ru

\section{Plakat 38}

Autor: nieznany

Tytuł: Najwyższa ostrożność, we wszystkich jednostkach, zawsze pamiętaj o podstępie i podłości wroga

Źródło: http://eng.plakaty.ru

\section{Plakat 39}

Autor: Viktor Semenovich Ivanov, 1945

Tytuł: Wróg jest podstępny - bądź czujny!

Źródło: http://eng.plakaty.ru

\section{Plakat 40}

Autor: Solomon Boim, 1945

Tytuł: Przechodząc za rubieże ojczystej ziemi bądźcie szczególnie ostrożni!

Źródło: http://eng.plakaty.ru

\section{Plakat 41}

Autor: Viktor Nikolaevich Denisov, Nikolaj Andreevich Dolgorukov, 1941

Tytuł: Każde uderzenie młota, uderzeniem we wroga

Źródło: http://eng.plakaty.ru

\section{Plakat 42}

Autor: Kukryniksy, 1941

Tytut: Zbiór plonów groźnym uderzeniem we wroga

Źródło: http://eng.plakaty.ru

\section{Plakat 43}

Autor: Aleksei Alekseevich Kokorekin, 1942

Tytuł: Wszystko dla zwycięstwa! Od kobiet ZSRR dla frontu

Źródło: http://eng.plakaty.ru

\section{Plakat 44}

Autor: nieznany

Tytuł: Ural dla frontu

Źródło: http://www.rosjapl.info/rosja/plakat_wojna.php

\section{Plakat 45}

Autor: Viktor Semenovich Ivanov, 1941

Tytuł: Nasza prawda. Bijcie się do śmierci

Źródło: http://eng.plakaty.ru 


\section{Plakat 46}

Autor: Kukryniksy, 1941

Tytuł: Walczymy dobrze, kłujemy zaciekle, wnuki Suworowa, dzieci Czapajewa

Źródło: http://eng.plakaty.ru

\section{Plakat 47}

Autor: Kukryniksy, 1941

Tytuł: Napoleon doznat klęski, tak będzie i z zarozumiałym Hitlerem!

Źródło: http://eng.plakaty.ru

\section{Plakat 48}

Autor: Kukryniksy, 1941

Tytut: Biliśmy wroga kopia, biliśmy wroga karabinem i teraz stalowym orężem bijemy wroga, gdzie tylko go odnajdziemy

Źródło: http://eng.plakaty.ru 